\title{
The first vs. second stage of neolithisation in Polish territories (to say nothing of the third?)
}

\author{
Marek Nowak \\ Institute of Archaeology, Jagiellonian University, Kraków, PL \\ mniauj@interia.pl
}

\begin{abstract}
The origins of the Neolithic in Polish territories are associated with migrations of groups of the Linear Band Pottery culture (LBK) after the mid-6th millennium BC. Communities of this culture only settled in enclaves distinguished by ecological conditions favourable to farming ('LBK neolithisation'). This situation persisted into the $5^{\text {th }}$ millennium $B C$, when these enclaves were inhabited by post-Linear groups. This state of affairs changed from c. 4000 BC onwards due to the formation and spectacular territorial expansion of the Funnel Beaker culture (TRB). In the territories under consideration this expansion covered the areas previously inhabited by both hunter-gatherers ('TRB neolithisation') and farmers. Some of the Late Mesolithic hunter-gatherers did not accept TRB patterns. They successfully carried on their traditional lifestyle until the Early Bronze Age although some changes in their material culture are visible (including 'ceramisation').
\end{abstract}

KEY WORDS - Poland; neolithisation; LBK; TRB; para-Neolithic

\section{Primerjava prve in druge stopnje neolitizacije na območju Poljske (da o tretji sploh ne govorimo)}

\begin{abstract}
IZVLEČEK - Začetki neolitika na območju Poljske so povezani z migracijami skupin linearno trakaste kulture (LTK) v drugi polovici 6. tisočletja pr. n. št. Te skupine so se naselile v enklavah, za katere so značilne ekološke razmere ugodne za kmetijsko ('neolitizacija LTK'). Takšno stanje se je ohranilo do 5. tisočletja pr. n. št., ko so te enklave poselile po-linearne skupine. Poselitev se je bistveno spremenila šele od ok. 4000 pr. n. št. naprej z oblikovanjem in spektakularnim širjenjem nosilcev kulture lijakastih čaš. Na Poljskem je ta poselitev zajela tudi območja, ki so jih pred tem poseljevali tako lovci in nabiralci ('neolitizacija kulture lijakastih čaš') kot poljedelci. Nekatere skupine pozno mezolitskih lovcev in nabiralcev niso sprejele vzorca kulture lijakastih čaš in so uspešno ohranili svoj način življenja vse do zgodnje bronaste dobe, čeprav lahko zaznamo nekatere spremembe v njihovi materialni kulturi (tudi 'keramizacijo').
\end{abstract}

KLJUČNE BESEDE - Poljska; neolitizacija; linearno trakasta kultura; kultura lijakastih čaš; para-neolitik

The present-day territory of Poland (Fig. 1) was and is situated in the borderland of different environmental (Rdzany 2014) but also different cultural, prehistoric, and historic formations (Davies 2005). In the period discussed here this resulted in different types of Neolithic culture, and different faces of neolithisation. These variants of the Neolithic and neolithisation developed in parallel for a relatively long time, coming into various interactions in the process. This situation is fairly unique for the entire European continent.

As in other parts of Central Europe, the origins of the Neolithic in the region in question are associated with the appearance of the Linear Band Pottery culture (LBK) (Fig. 2) after the mid-6th millennium 
BC (Czekaj-Zastawny 2008; 2009; 2017; Grygiel 2004; Kulczycka-Leciejewiczowa 2000; Pyzel 2010). We still do not have genetic data from the 'Polish' LBK. However, such data from nearby Hungary, Austria, and Germany (Ammerman et al. 2006; Bramanti et al. 2009; Brandt et al. 2015; Burger et al. 2006; Haak et al. 2005; 2010; 2015; Lazaridis et al. 2014; Lipson et al. 2017; Mathieson et al. 2018; Szécsényi-Nagy et al. 2015) demonstrate genetic dissimilarities between LBK and central-European, huntergatherer populations and the predominance of the so-called north-western Anatolian Neolithic component among the former ones. In conjunction with distinct similarities and even uniformities in material culture between the LBK north and south of the Carpathians and Sudetes (compare,

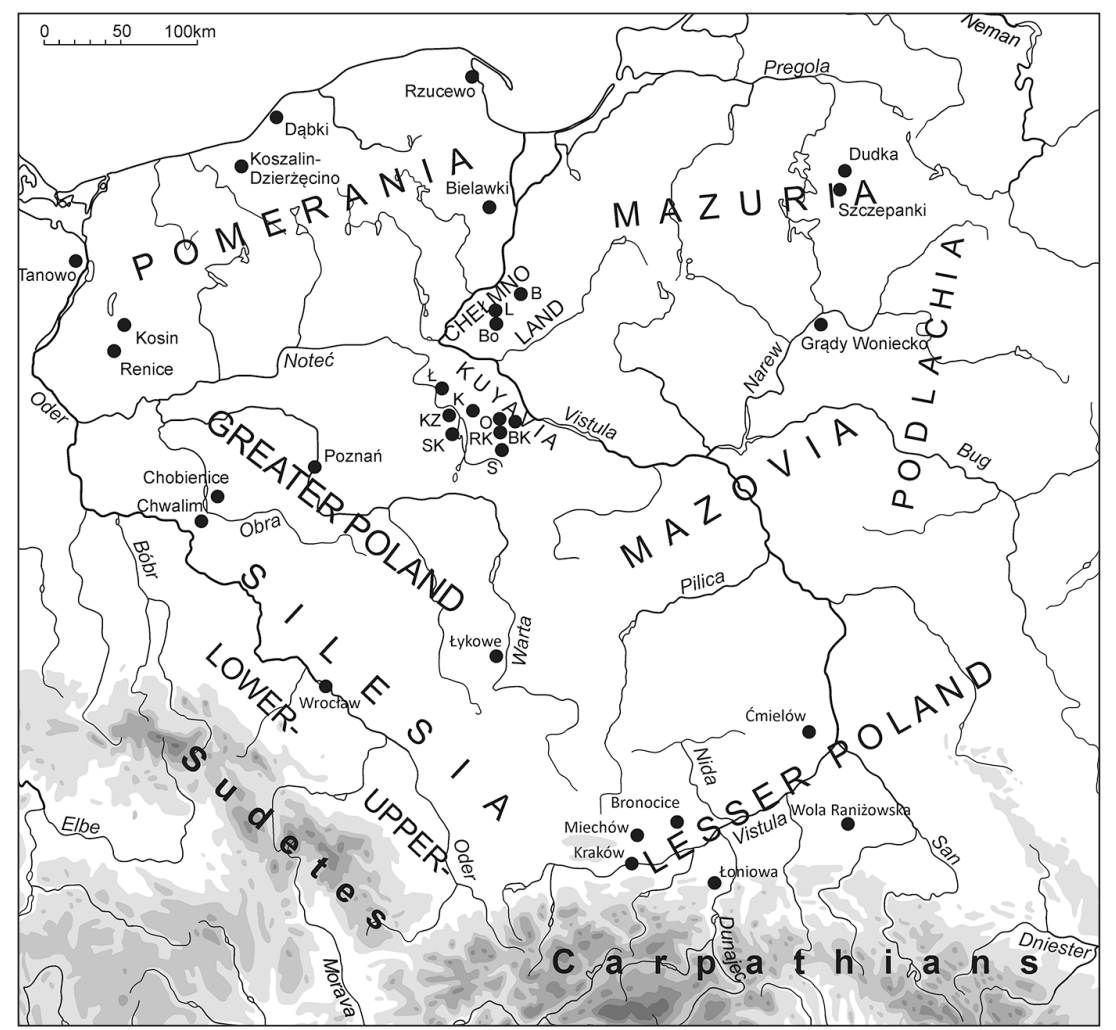

Fig. 1. The location of the study area with archaeological sites and towns mentioned in the text and figures (B Boguszewo, Bo Bocień, BK Brześć Kujawski, K Konary, KZ Krusza Zamkowa, L Lisewo, Ł Lącko, 0 Ostonki, RK Redecz Krukowy, S Sarnowo, SK Strzelce Krzyżanna).

for example, Czekaj-Zastawny 2014; 2017; and Pavlì, Zápotocká 2007; 2013), this makes migrations from the south the most probable scenario of the origins of the LBK in Polish territories. On the other hand, a very modest but quite pervasive proportion of hunter-gatherer ancestry in quoted, European genetic data (i.e. including even the Balkan Neolithic) should be emphasized. Thus, some contacts between incoming early farmers and local hunter-gatherers had to exist, even if these were only casual sexual contacts. It is also characteristic that participation of the hunter-gatherer component is higher in Germany than in Transdanubia (Lipson et al. 2017). This would mean that during the LBK spread outside the 'cradle' area, the Neolithic-Mesolithic contacts became more intense. Consequently, such a scenario can be also applied to the LBK spread in the Vistula and Oder basins.

Perhaps it is worth noting here that genetic data obtained in the $21^{\text {st }}$ century have demonstrated that classical constructs - deriving inter alia from the works by Vere G. Childe (e.g., 1929; 1947) as well as Albert J. Ammerman and Luigi L. Cavalli-Sforza (e.g., Ammermann, Cavalli-Sforza 1984; CavalliSforza et al. 1994) - which presented the LBK as a continuation of the Anatolian-Balkan First Neolithic, in principle seem to be true (cf. Hofmann 2015). Certainly, many details of these constructs were amended or eradicated due to new data, both genetic and archaeological ones. For instance, the crystallisation processes of the LBK that took place in the north-western parts of the Carpathian Basin filtered and changed the First Temperate Neolithic (FTN) cultural pattern (e.g., Bánffy 2004; 2006; 2019; Bickle et al. 2013; Stadler, Kotova 2010; Whittle et al. 2013), regardless of how they are interpreted. However, for a follower of the allochtonic position the 'Mesolithic' hypotheses, which assumed substantial or even exclusive role of Mesolithic acculturation (e.g., Bánffy 2004; 2006; Bánffy et al. 2007; Bentley et al. 2013; Mateiciucová 2008; Whittle 1996. 150-152), currently do not seem particularly convincing. Perhaps it is characteristic that in the very recent publication by Eszter Bánffy (2019) the particular emphasis has been placed on transformations between Starčevo-Körös and LBK in the patterns of architecture and husbandry.

As a matter of fact, the latter hypotheses have never become fully entrenched in Central European culture-historical archaeology (cf. Gronenborn 2007). 
Therefore, the followers of the culture-historical approach may undoubtedly take some satisfaction from the fact that its traditional analytical methods have proven to be not so completely useless after all. This does not mean that the consciously and unconsciously used paradigms of culture-historical archaeology, relevant in this context, should always be considered as true. To such paradigms belong, for example, convictions about the decisive role of migration in cultural changes and - as a consequence - the negligible participation of hunter-gatherers in neolithisation.

In light of the currently available radiocarbon dates we can draw a picture of a very rapid initial expansion that started in western Lesser Poland and proceeded along the Vistula River to Kuyavia and Chełmno Land as well as eastward, to the upper Bug River basin (Fig. 3). In both cases this expansion basically took place in the $54^{\text {th }}$ century BC. This fits very well to the scheme proposed a few years ago by Janos Jakucs et al. (2016), despite the fact that their research hardly used absolute dates of the LBK from Poland. Another axis of LBK migrations - Wrocław - Poz-
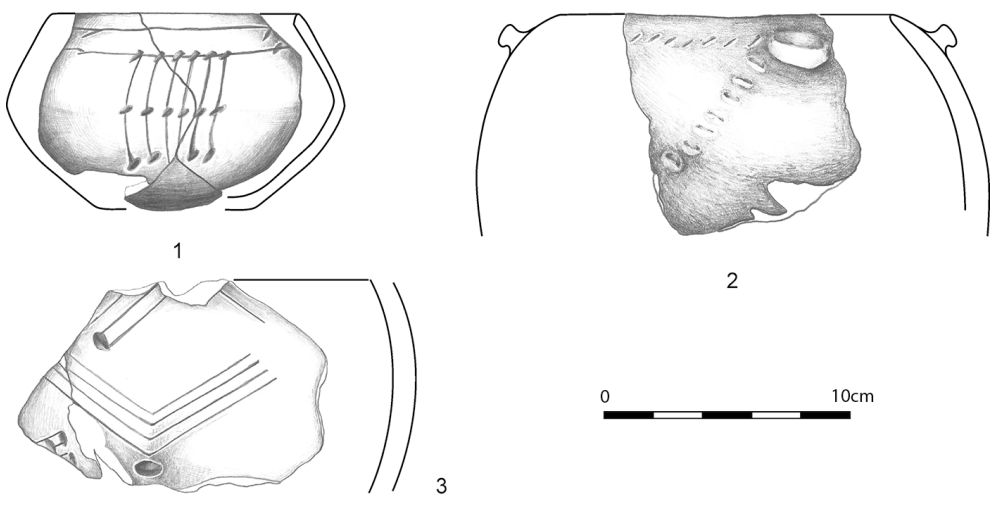

2
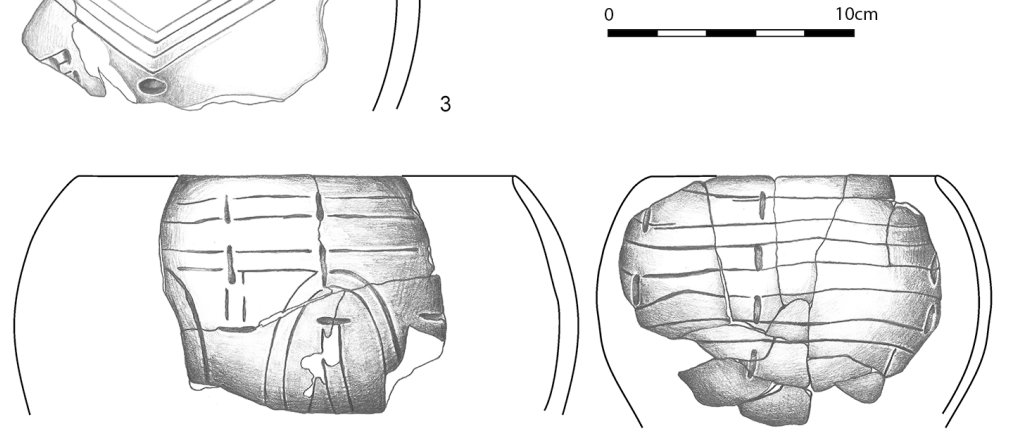

4

5

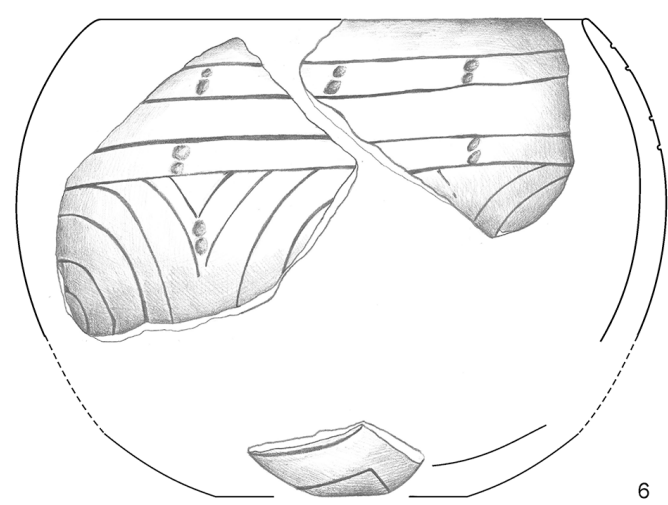

Fig. 2. Examples of the LBK pottery from site 3 in Miechów (drawn by S. Krishnevskaya; layout by $U$. Bakk). nań - Kuyavia/Chełmno Land/Western Pomerania started to function later. One way or another, this means that the beginnings of LBK in Polish territories, and not only here (cf. Jakucs et al. 2016), should be placed later than previously believed, that is around $5400 \mathrm{BC}$ at the earliest. In the cited publication the beginnings of the LBK 'formative phase' around 5500 $\mathrm{BC}$, or perhaps within the $56^{\text {th }}$ century $\mathrm{BC}$, are referred only to Transdanubia and Lower Austria ( $\mathrm{Ja}$ kucs et al. 2016.323-324, 329).

One should also raise another issue here, one not related to the territory of present-day Poland alone. When speaking of the LBK, we usually have in mind the image of a great LBK 'empire', stretching continuously from the Paris Basin to western Ukraine, and even to Moldova and the eastern part of Wallachia. This is mainly due to a map developed by Jens Lüning (1988), later repeatedly reproduced and used in many publications (e.g., Bogucki, Grygiel 1993), although this was naturally not the only cartographic depiction functioning in the literature (e.g., Price, Bentley 2005.Fig. 3). However, Lüning's map is a far-reaching simplification, because the real picture of LBK distribution looks quite different. Communities of that culture first and foremost settled zones with a prevalence of ecological conditions favourable to farming. As a consequence, LBK sites distinctly concentrate within enclaves ('islands') of different sizes, even very small ones. Such enclaves were separated by vast areas with either a very low density of LBK settlement or literally deprived of it (e.g., Czekaj-Zastawny 2009; Kulczycka-Leciejewiczowa 1993). The patchy character of the early farming spread was certainly noticed ( $c f$. Robb 2013. 658 ), but it was reflected relatively poorly in general interpretations.

As a matter of fact, the appealing idea, one that is repeatedly presented in such general contributions, 


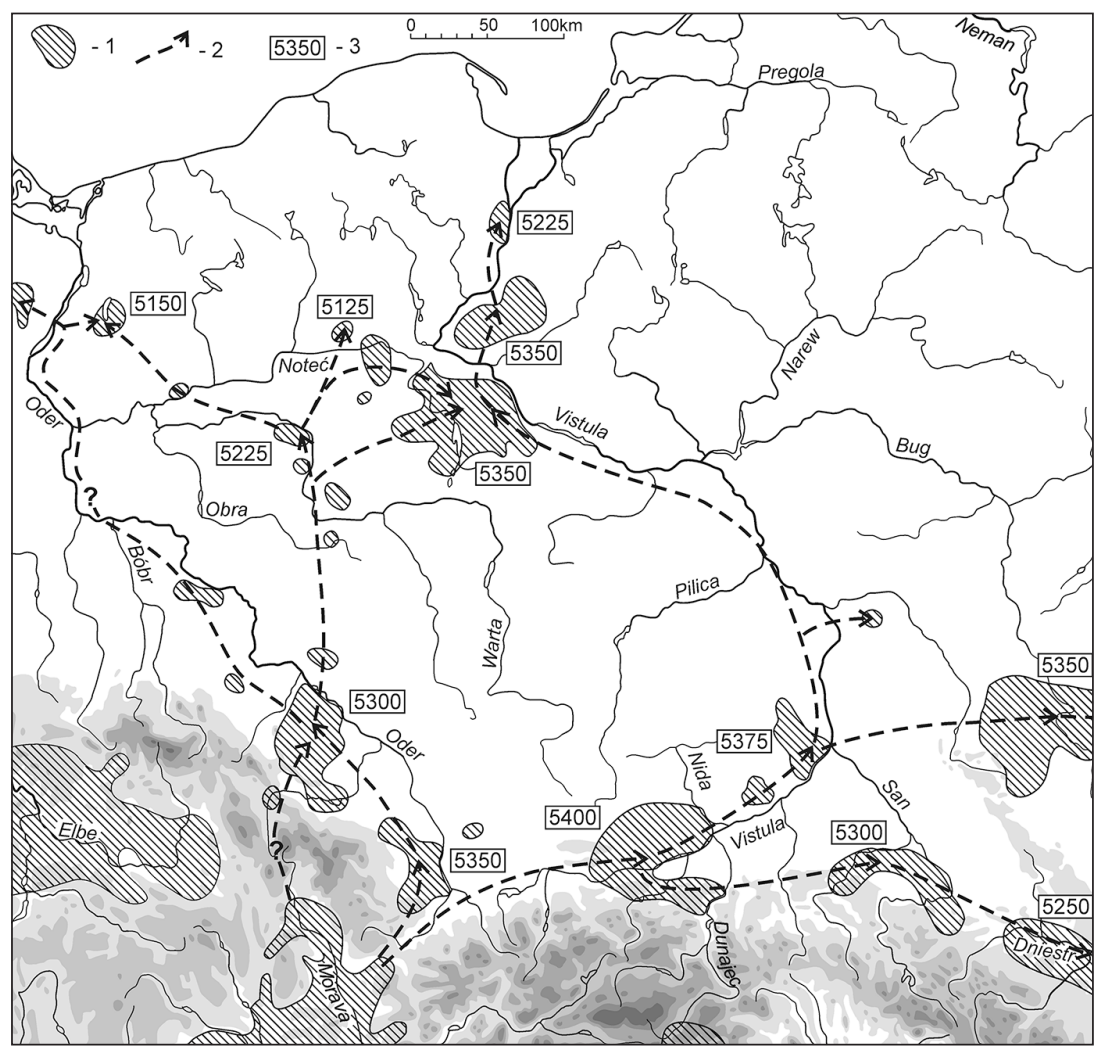

Fig. 3. The spread of the LBK in Polish territories. 1 enclaves settled by the LBK communities (in the period of greatest territorial extent, i.e. in the classical and late phases); 2 basic routes of migrations of the LBK groups (in the period of stabilisation they became axes of contacts between settlement enclaves); 3 averaged datings of the appearance of the LBK in a given area.

of a single, uninterrupted front between the Neolithic and Mesolithic populations running latitudinally across the whole of Central Europe (e.g., Fernández et al. 2014; Silva, Vander Linden 2017) is untrue. In fact, the borderline between these two formations was incomparably longer and had a far more complex course, particularly during the peak of LBK development. The relation between these two cultural entities can also alternatively be presented as a co-existence of two communication systems (Fig. 4) (Koztowski, Nowak 2018a; 2018b). On the other hand, one should emphasize that LBK communities did not cling to the most fertile soils. Recent years have produced a growing body of LBK finds from sandy soils, and not only from lowlands. Strikingly, however, these sites are always situated close to fertile soils, not further than a few kilometres away, and sometimes simply in sandy enclaves within such soils (e.g., Pyzel 2010).

As in other central European countries, the LBK in Poland comprises all elements of what is known as the Neolithic Package (Czekaj-Zastawny 2017; Grygiel 2004). It is significant (particularly from the per- spective of the LBK origins) that these elements, in full suite and in evident predominance, are distinctly recordable even from the very beginning of this culture. In other words, the LBK appeared in Polish territories as a developed, operational cultural model. We can only express, one more time after many authors, our bewilderment at the far-reaching stylistic uniformity within the archaeological unit that covered vast territories of central Europe, including Poland, and some neighbouring areas. Significant similarities in terms of diet, health conditions and residence patterns have also been underlined (e.g., Hedges et al. 2013). This does not mean that all LBK constituents were identical, and that there were no local specificities and outliers (Whittle, Bickle 2013).

It is somewhat paradoxical that in the archaeological literature the LBK constitutes perhaps the most textbook example of a Neolithic formation and Neolithic Package in central Europe, despite its early position within this period. This is perhaps best illustrated by highly typical LBK houses, commonly called longhouses (although not all of them are actually long) (Fig. 5). As a matter of fact, they are the most solid, durable, and evident house constructions throughout the whole central European Neolithic (sensu largo, i.e. including also the Eneolithic). One may wonder whether this implies some unique position of such houses in the settlement and social structures of LBK communities. Unfortunately, although these structures have been very comprehensively described and many interesting interpretations have been proposed (e.g., $\mathrm{Ha}$ mon et al. 2013; Lüning 1988; Modderman 1988; Oross et al. 2016; Pavli 2000; Pyzel 2010; 2012; Rück 2007; 2012; Werra 2010; 2012), one can hardly argue that this has brought us closer to any clear conclusions concerning their function or even the number of people living in such houses. The remains of perhaps more than 500 have already been uncovered in Poland. They are known from LBK settle- 
ments of different sizes and are situated in different environments. Nevertheless, one should emphasize that there are sites where remains of such houses have not been identified (Fig. 6). It is hard to solve the problem whether in all such cases these remains were destroyed by erosional processes or there existed some LBK settlements without longhouses.

Cultural and spatial arrangements typical for Polish territories during the LBK period also persisted in the $5^{\text {th }}$ millennium BC. Different Neolithic groups of a post-Linear character, which traditionally have also been called Younger Danubian Communities, still concentrated within the same enclaves (Kadrow 2017; Nowak 2009). As in other areas previously occupied by the LBK, the uniformisation of pottery can no longer be observed ( $c f$. Robb 2013.665), a phenomenon which was already detectable at the close of the LBK development 1 . In other aspects of the cultural system, however, no radical transformation can be seen. The fundamental patterns of settlement and economy seem to have remained largely unchanged. For example, situations where sites used in the LBK period were also used, albeit not necessarily uninterruptedly, by Younger Danubian communities, were commonplace (see for instance again Miechów 3 - Figs. 7, 8). Undoubtedly, some areas outside these enclaves were penetrated and even settled and exploited by Neolithic groups, like some parts of Greater Poland, eastern Pomerania or even Mazuria. However, this does not undermine the fact that until the end of the $5^{\text {th millennium BC at least }}$ approx. $70 \%$ of the territory under discussion still remained beyond the extent of compact Neolithic settlement (Kozłowski, Nowak 2018b).

However, in the second half of the $5^{\text {th }}$ millennium BC pottery appears outside the context of Younger Danubian communities. Technologically and stylistically it stands very close to east-European Neolithic units, for instance the Dnieper-Doniec or Narva cultures. We should mention here early Zedmar ceramics in the Masurian Lake District (Kozicka 2017),
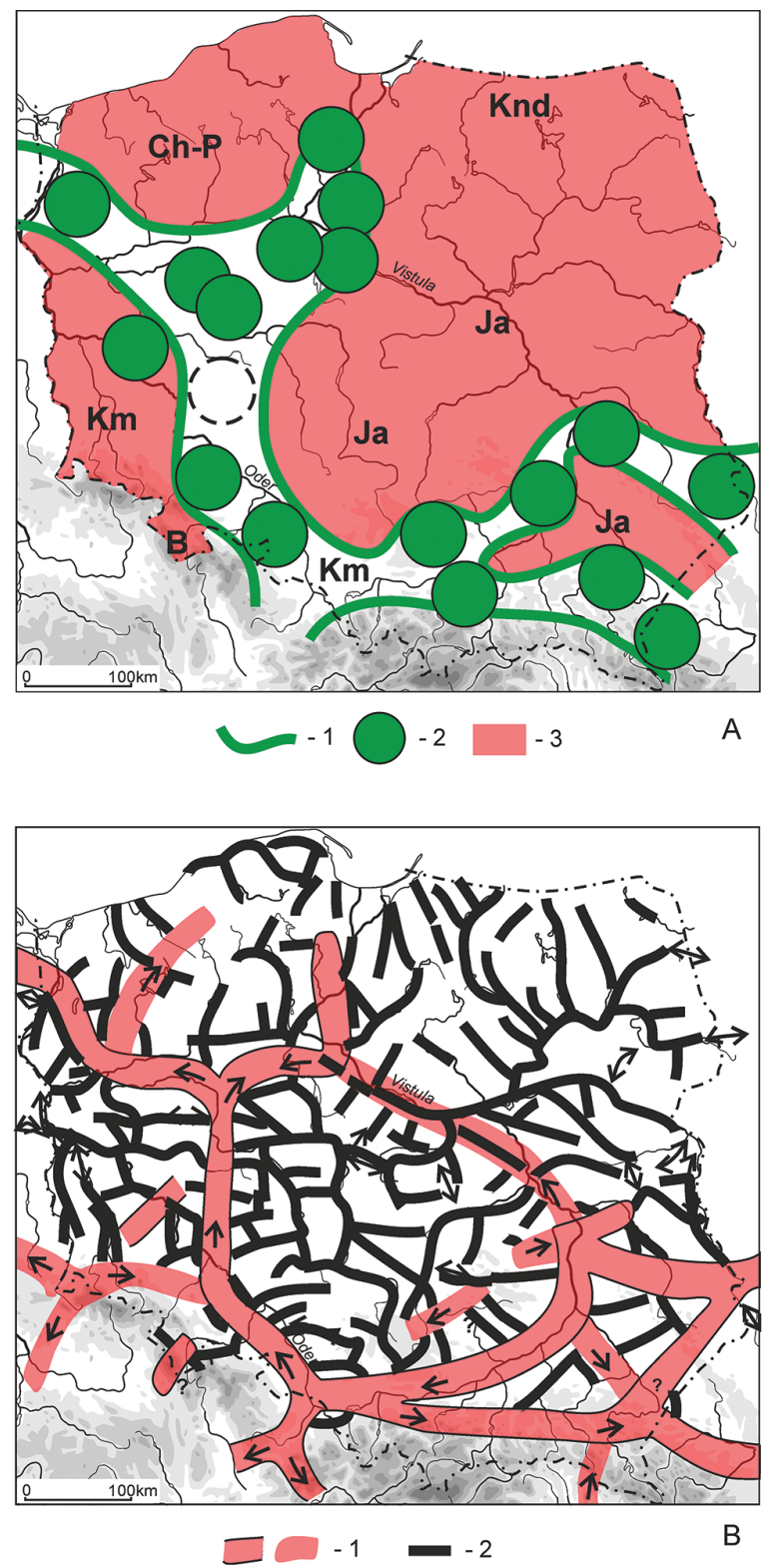

Fig. 4. Confrontation of the first farmers and the late hunter-gatherers in east-central Europe (Koztowski, Nowak 2018b). A the first contact: the LBK (1-2) and the Late Mesolithic cultures (3) (B Beuronien, Km Komornica, Ch-P Chojnice-Pieńki, Ja Janistawice, Knd Kunda); B the road map of the $6^{\text {th }}$ millennium BC (1 the Early Neolithic 'motorways' and delivery roads; 2 the Mesolithic paths).

1 The side effect is that a number of cultural units have been distinguished in the archaeology of Poland in the $5^{\text {th }}$ millennium $\mathrm{BC}$, some of which are rather poorly defined. This drives discussions on taxonomical divisions, with new propositions overlying previous ones. For example, the same archaeological phenomenon is referred to as the Brześć Kujawski group, Brześć Kujawski culture, Late Linear Band Pottery culture (phases II and III), Brześć Kujawski group of the Lengyel culture, etc. Since these discussions are generally carried out only in Polish-language literature, they remain largely unknown outside this milieu. As a result, archaeologists from other countries may have an impression of terminological chaos, and sometimes use some of the terms in a simply incorrect manner (e.g., regarding the above-mentioned cultural unit as a late phase of LBK). Perhaps the best remedy for this situation (regardless of the general terms mentioned above, such as post-Linear or Younger Danubian Communities) is to apply the most classic approach, in which the decline of LBK is followed by the development of the Stroked Pottery culture in western Poland in the first half of the $5^{\text {th }}$ millennium BC, and the so-called Lengyel-Polgár cycle/complex. The latter term covers more than a dozen smaller groups developing in the $5^{\text {th }}$ and early $4^{\text {th }}$ millennia $\mathrm{BC}$ throughout most of Poland (within the enclaves discussed in the text). The trait shared by these groups is their strong dependence on cultural patterns created in that time in the Lengyel and Tisa cultural centres. 


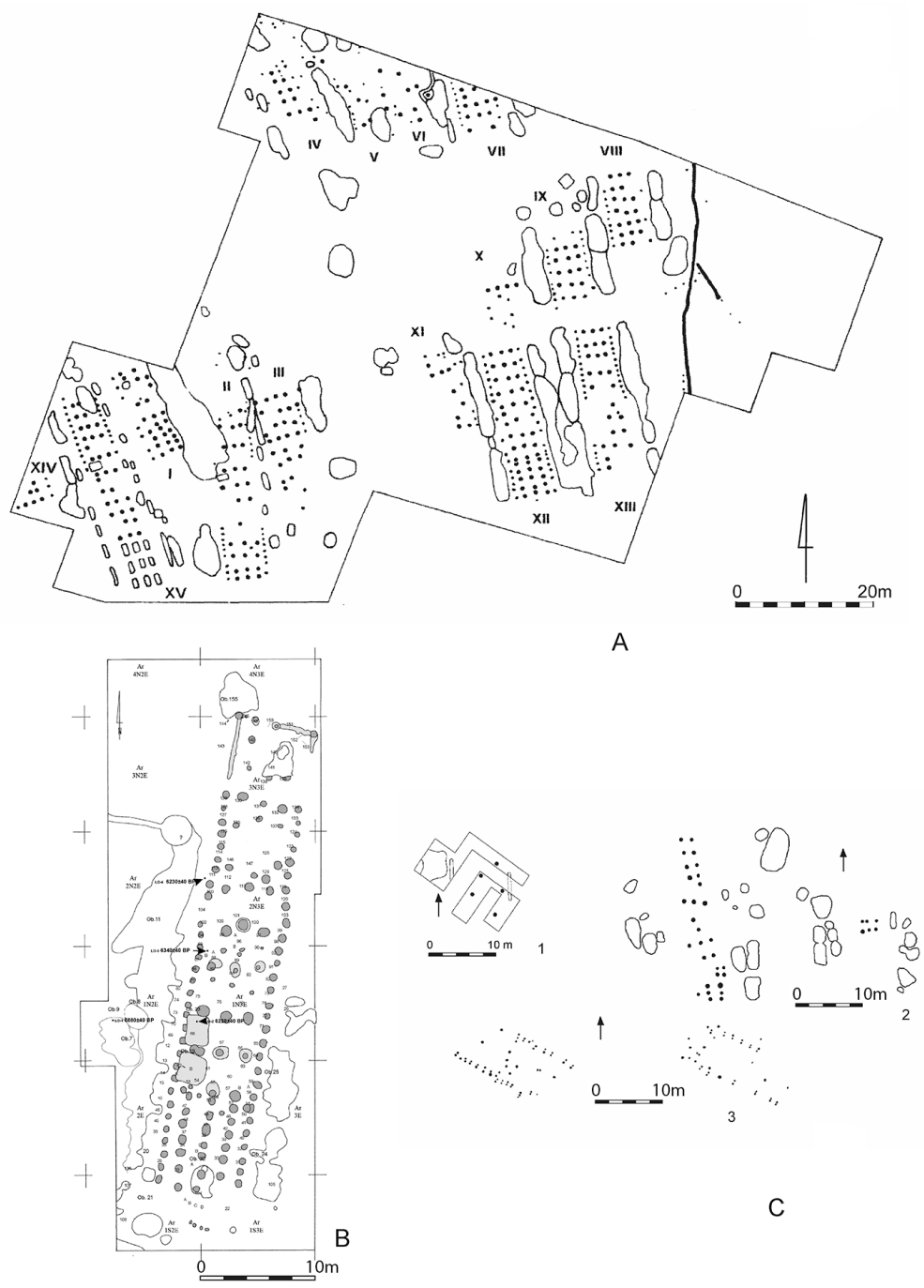

Fig. 5. Examples of the LBK longhouses from different environmental zones. A upland zone (Brzezie 17; Czekaj-Zastawny, Zastawny 2006); B mountainous zone (Loniowa 18; Valde-Nowak 2009); C lowland zone (1 Boguszewo 43a, 2 Bocień 5, 3 Lisewo 31; Werra 2012). or post-Linear units. In practice, it is pottery that constitutes the only element of the Neolithic Package present there (e.g., Piezonka 2015; Rimantiene 1992; 1994). In other words, in the eastern European literature the term 'Neolithic' has a very different meaning as compared to in the central or western European literature. Actually, we are dealing here with the incompatibility of notional apparatuses used with respect to the discussed period by different schools of research. More precisely, we are dealing with differently understood Neolithics, if we insist on using the term Neolithic at all.

To complicate the issue further, a similar phenomenon, i.e. the presence of pottery in the hunter-gatherer context dated to the $5^{\text {th }}$ millennium $\mathrm{BC}$, was recorded in the northern fringes of Poland (Fig. 10). One should mention in this context at least three sites: Tanowo (Galiński 2016), Dąbki (Kabaciński et al. 2015), and Rzucewo (Król 2018). The beginnings of this phenomenon can be dated at $c .4800 / 4700 \mathrm{BC}$, at least in the case of Dąbki. The pottery in question is more or less similar to the pottery of the Ertebølle culture (EBK). Combined with the dating this is interesting, as this means that this pottery is not much and single vessels of the Dubičiai (Prypat'-Neman) type in north-east Poland (Józwiak 2003; Kempisty, Sulgostowska 1991) (Fig. 9).

As for the spread of this phenomenon, which was independent of the FTN/LBK and Cardial/Impressa neolithisations, it progressed, generally speaking, among local, hunter-gatherer populations by way of acculturation. This is also demonstrated by 'new' genetic data from the Baltic countries (Mittnik et al. 2018) and slightly 'older' data, including several samples from north-east Poland (Bramanti et al. 2009). Certainly, some movements of the hunter-gatherer groups cannot be ruled out.

However, it is necessary to underline that this eastEuropean Neolithic, including the Polish sites, differs considerably from, for example, Balkan FTN or LBK later than the EBK proper (Hartz, Lübke 2005; 2006; Hartz et al. 2000; Terberger 2000). We must not forget, however, that the dating of EBK and similar pottery is generally problematic due to the particularly strong impact of the marine reservoir effect. Nevertheless, it needs to be stressed that in Dąbki, Tanowo, and Rzucewo the pottery appears in the context of the local Mesolithic. In terms of the flint industry, this is not EBK but the post-Maglemose Chojnice-Pieńki culture, in its developed phase.

As regards these finds, from the eastern European perspective we could say that we are dealing here with neolithisation and the Neolithic. However, it is extremely telling that the investigators of Dąbki, Tanowo, or Rzucewo never used such terms. For them it was first and foremost an example of ceramisation of local Late Mesolithic groups. The same approach 
currently prevails with respect to several similar northern German sites, and actually to the entire EBK as such.

The relation between the Ertebølle pottery (sensu largo) and the pottery of the east-European Neolithic is another issue, and different views have been expressed in this respect (such as Czerniak, Pyzel 2011; Dumpe et al. 2011; Kabacinski, Terberger 2011). These potteries are indeed similar, although no obvious intermediate link can be identified in the southern Baltic basin. Perhaps Dąbki could be such a link given the possibly early occurrence of pottery in this site. However, to discuss the issue in more detail is beyond the scope of this paper, and we only hint at a possible solution.

Contacts between farming and hunting-gathering groups seem to have been rather limited during the $5^{\text {th }}$ millennium BC, similar to the situation in the second half of the $6^{\text {th }}$ millennium BC. They are evidenced by single finds of pottery and stone tools belonging to older and younger 'Danubians' beyond their oecumene, including those in direct hunter-gatherer contexts (see, for example, the Neolithic pottery in Dąbki - Czekaj-Zastawny 2015; Czekaj-Zastawny et al. 2011; Dudka, Szczepanki-Gumiński 2011).

Undoubtedly, it is worth paying a little more attention to some types of stone artefacts, which seem to reveal a little more about the potential Neolithic-Mesolithic relations at that time. Polished stone implements (axes and adzes) are a permanent element of the LBK cultural system, but also of the post-Linear ones (the latter fact is often forgotten). They were made mainly of Sudeten rocks, particularly amphibolites (Cholewa 2004; Prostřednik et al. 2005). Sporadically, we can also find tools of this kind made of erratic rocks, which suggest that local production was rarely undertaken (Prinke, Skoczylas 1980). Stone tools from Sudeten rocks are widespread within the LBK and post-Linear units (e.g., Ramminger 2009). There had to exist an organized distribution network for them that served all clusters of 'Older' and 'Younger' Danubians, more or less distant from the Sudeten Mountains. Perhaps this system contributed to maintaining a mental and ideological commonality among these areas (the notion of an 'imagined community' proposed by Alasdair Whittle and Penny Bickle (2013) seems to be a good description of this phenomenon). We can suppose their non-utilitarian significance, due to their frequent presence in male graves. In this respect, let us mention the re-

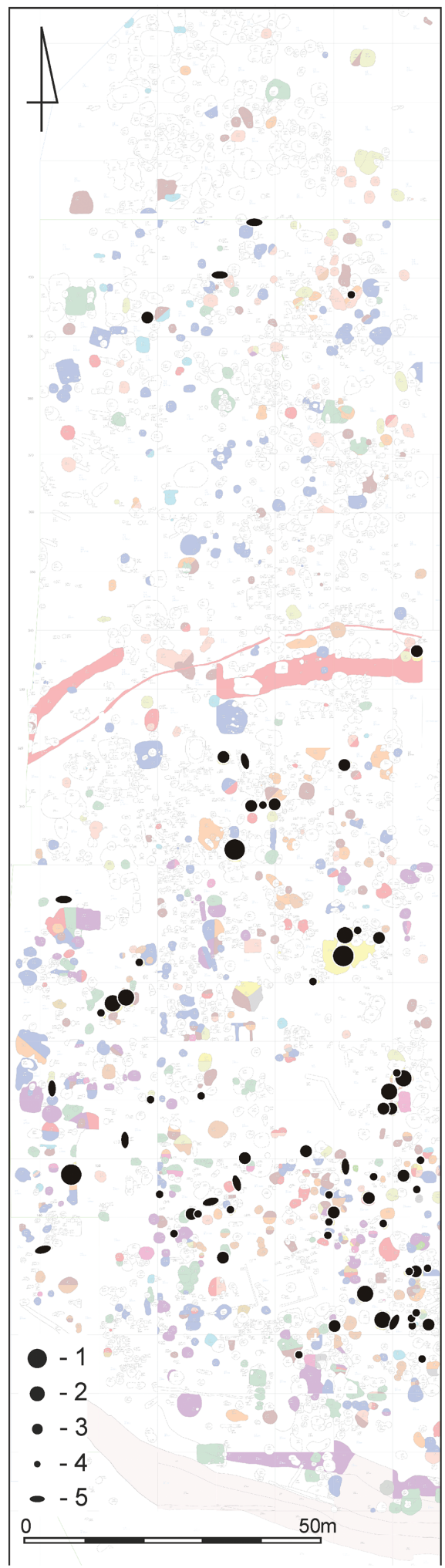

Fig. 6. The LBK settlement at the multi-period site 3 in Miechów against the blurred background of features belonging to other archaeological units; the LBK features are highlighted by graphic symbols. 1 features with longer axis over $5 \mathrm{~m} ; 2$ features with longer axis 3-5m; 3 features with longer axis 1-3m; 4 features with longer axis less than 1m; 5 extremely elongated features (mostly burials). 


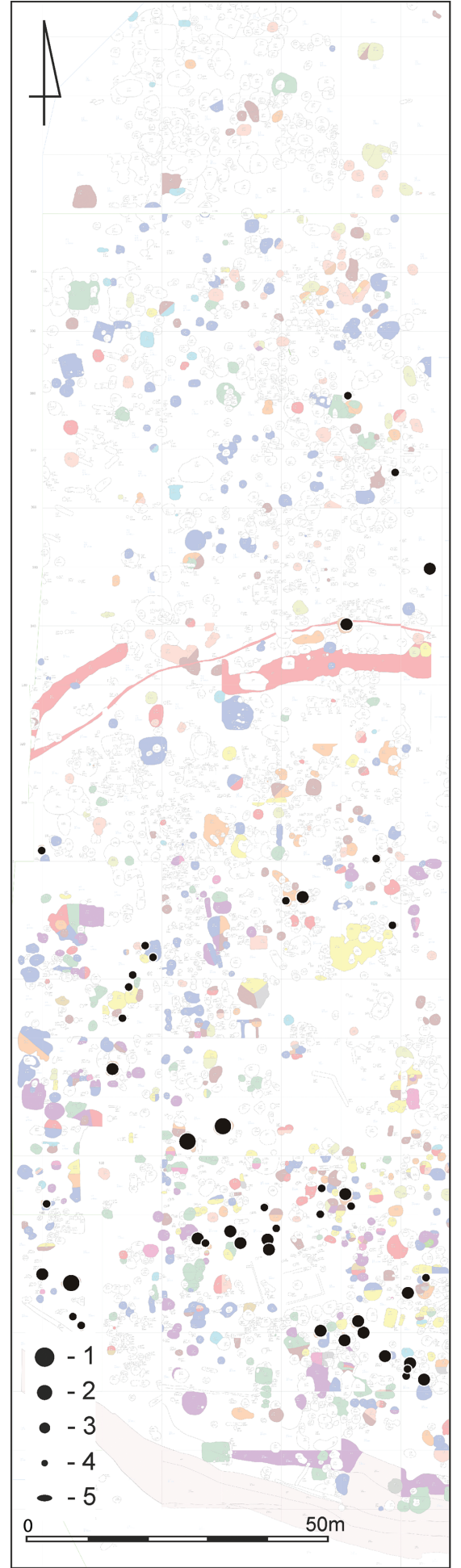

Fig. 7. The settlement of the Lublin-Volhynian culture (late stage of the Younger Danubian communities/Lengyel-Polgár complex) at the multi-period site 3 in Miechów against the blurred background of features belonging to other archaeological units; the Lublin-Volhynian features are highlighted by graphic symbols. 1features with longer axis over $5 \mathrm{~m}$; 2 features with longer axis 3-5m; 3 features with longer axis 1-3m; 4 features with longer axis less than 1m; 5 extremely elongated features. cent, exceptionally interesting discovery of a cremation burial ground in Modlniczka 5 (Czekaj-Zastawny, Przybyta 2012), where stone adzes constituted the only category of grave goods (although, of course, the identification of sex was not possible there).

However, more important for us is the fact that these items are also present in areas beyond the compact range of the Linear and post-Linear settlements, stretching from the Netherlands to Pomerania and central Poland. By convention, these areas can be called a Mesolithic oecumene. The map published several times by Marek Zvelebil (1998.Fig. 1.6; 2001.Fig. 4) is very meaningful here, and should be supplemented for Poland with data by Kazimierz Siuchniński (1969), Andrzej Prinke and Janusz Skoczylas (1980) and Jolanta Ilkiewicz (2005). All these records show that numbers of finds of this kind are very high: probably hundreds, if not thousands.

The problem is that the vast majority of these finds are devoid of archaeological context, i.e. they were not found directly in Mesolithic sites. Danubian axes and adzes found directly in such contexts are rather rare, and are actually limited to only a few sites in northern Germany and Denmark, while in Poland only the site of Dąbi can be noted. This observation, however, confirms the supposition resulting from the cartography of 'Danubian' stone tools, which is that they in any case entered the Mesolithic environment. We can therefore hypothesize that these products were an element of Neolithic-Mesolithic interactions (mainly commercial?), which did not take into account the 'cultural' borders.

Another possible hint on Neolithic-Mesolithic contacts are Mesolithic traces in the maternal genetic pool of the Younger Danubian groups in Kuyavia (vide the sites of Osłonki, Konary, Krusza Zamkowa, Brześć Kujawski - Juras et al. 2017; Lorkiewicz et al. 2015), although, as stated in a recent study by Daniel M. Fernandes et al. (2018), the Brześć Kujawski group (excluding two outliers) is certainly composed of the same genetic component present among Anatolian and LBK Early Neolithic farmers.

Summing up the above discussion, one can conclude that, until the end of the $5^{\text {th }}$ millennium BC, the cultural picture of Polish territories was shaped by three main components. First, there were enclaves settled by Older and Younger Danubian communities, which represented a complete Neolithic Package, as well as 'routes' and 'motorways' connecting them. Second, in the $5^{\text {th }}$ millennium $\mathrm{BC}$, most likely in its second 
half, the east-European Neolithic encroached from the east, while in the northern peripheries we can observe a similar process, this time according to the Ertebølle patterns. In both cases it was first and foremost the ceramisation of the local Mesolithic substratum. However, the adoption of pottery by hunter-gatherer groups was still a very local and limited phenomenon. Finally, the third component of this picture is obviously the late, non-ceramised Mesolithic communities, which in that time were still present everywhere (Kozłowski, Nowak 2018a; 2018b; Nowak 2009), even in the south (Nowak et al. in press; Pazdur et al. 2004).

From the late $5^{\text {th }}$ millennium $\mathrm{BC}$ onwards, complex cultural transformations started to take place in the Vistula and Oder basins. They were associated with the spread of a new model of farming culture throughout most of the discussed part of Europe, and not only the above-mentioned fertile enclaves. This new model, known to archaeologists as the Funnel Beaker culture (TRB) (Fig. 11), actually covered a much larger area, from the Netherlands to western Ukraine, including the south-Scandinavian zone, where it marked the beginning of the Neolithic. In the Vistula and Oder basins, as in other territories within the TRB range, we can observe a phenomenon that can be called a filling-in of the landscape. A very large number of TRB sites are known, many more than those of the Danubian cultures (which in itself is puzzling), and they have been recorded in nearly all ecological zones, not only in the most fertile areas, as preferred by previous Neolithic settlement. This makes TRB the first Neolithic culture to have covered the previously not Neolithicized areas in the Vistula and Oder basins, which de facto means most of the territory of our interest. Therefore, this phenomenon, i.e. the spread of the 'Beaker' Neolithic to areas outside previous Neolithic (Danubian) occupation, was once called the second stage of Neolithisation (Nowak 2001; 2009). In the end, this process proved perhaps even more important than the first Neolithisation. One way or another the Neolithic formation

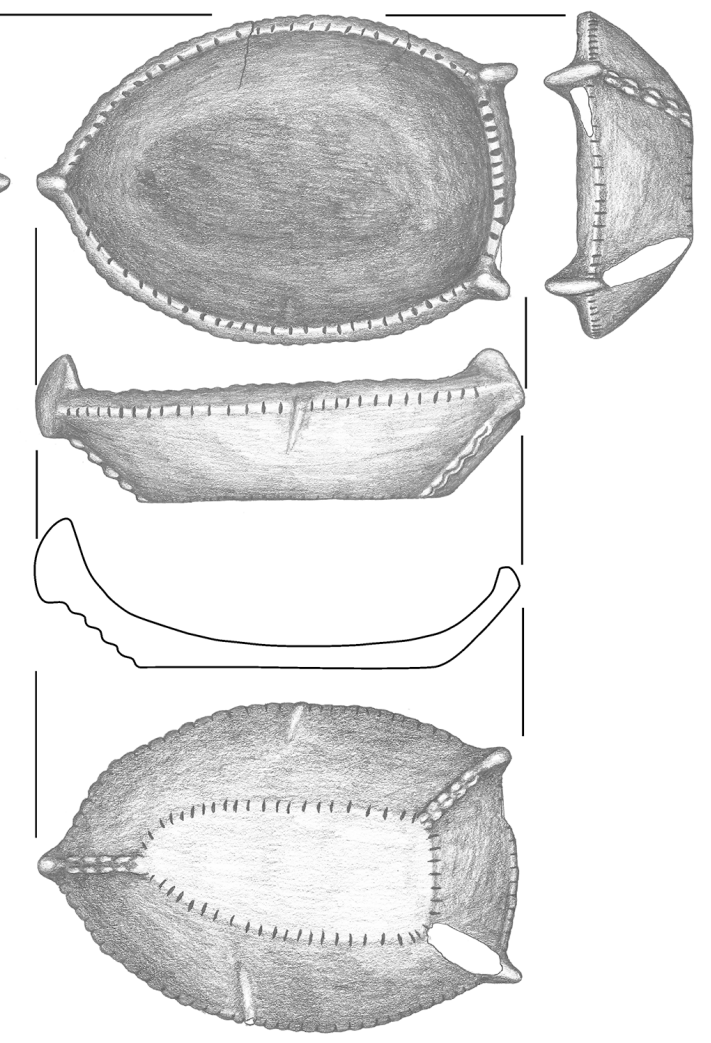

1

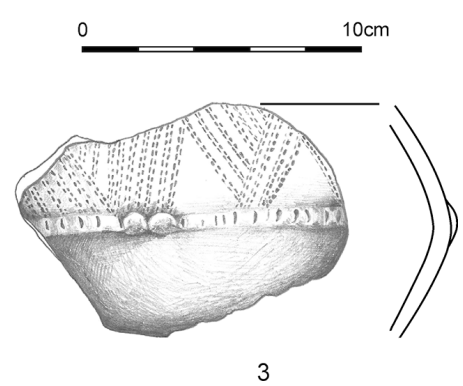

2

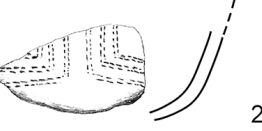

Fig. 8. Examples of pottery of the Malice culture (middle stage of the Younger Danubian communities/Lengyel-Polgár complex) from the site 3 in Miechów (drawn by S. Krishnevskaya; layout by U. Bak).

eventually filled, in a relatively compact manner, the majority of the Polish territories around the mid-4th millennium BC.

As an example of this filling in of the landscape one can present the case of central Greater Poland (Wierzbicki 2013). There are more than 3100 TRB sites and fewer than 150 sites of LBK and Younger Danubian Neolithic in the region, with TRB sites covering this area more or less uniformly (Fig. 12).

The basic problem associated with the described process is the genesis of TRB and the mechanism of its spread. This is surely one of the most controversial issues of the central European Neolithic, and it has long been discussed and analysed (such as Czerniak 1994; 2018; Grygiel 2016; Jażdżewski 1936; Kośko 


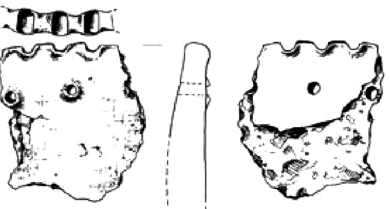

1

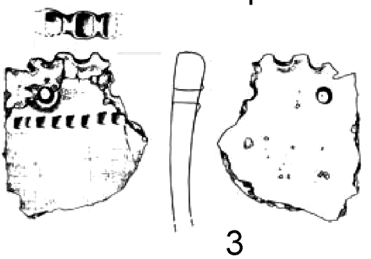

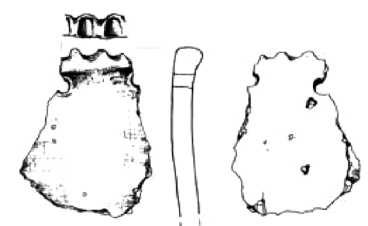

2

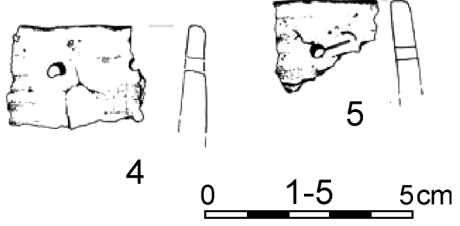

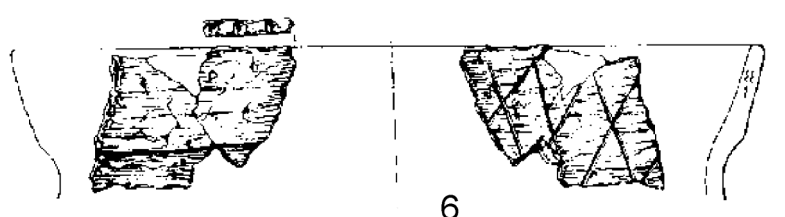

6

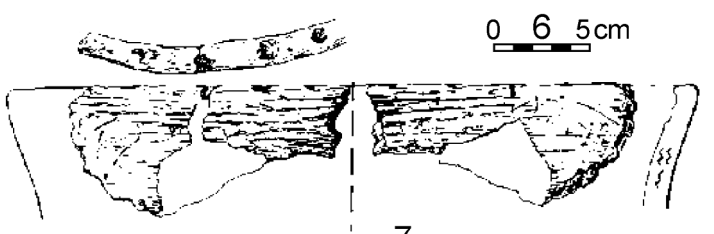

7
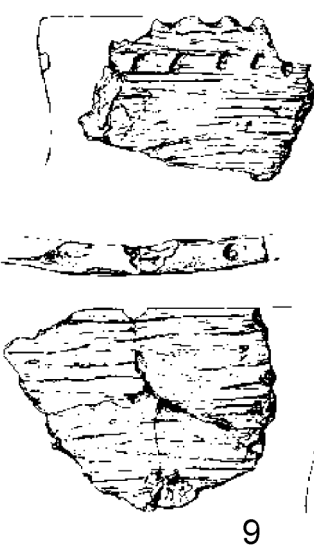

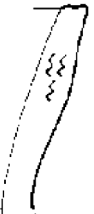

9
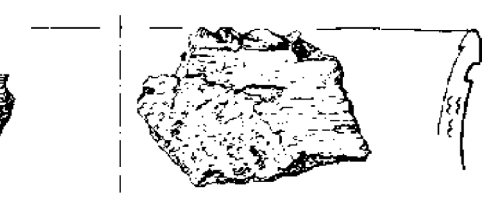

8
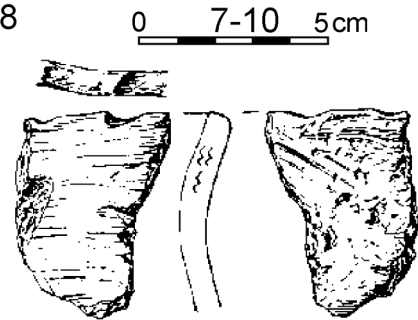

10
Fig. 9. Examples of the early para-Neolithic pottery. 1-5 Grady Woniecko, stylistic group I (Wawrusiewicz et al. 2017); 6-10 Woźna Wieś (Kempisty, Sulgostowska 1991).

1981; Kowalczyk 1970; Kukawka 2015; Nowak 2009; 2017; Wiślański 1979a), of course not only with respect to the territory of Poland (e.g., Fischer 2003). Without going into details, it should be emphasised that all these discussions are somewhat flawed due to their local scales. For example, the genesis of TRB in Denmark has been analysed as if the scholars were unaware that TRB also existed outside its northern group, or outside Denmark. And likewise, discussions on the issue carried out in Poland, hardly ever reach beyond the borders of Poland, as if the archaeologists have forgotten that TRB is present also elsewhere, for example in southern Sweden, the Netherlands, or Moravia.
At present, the chronological antecedence within the whole range of TRB should formally be given to the zone of the south-western Baltic coast, since radiocarbon dates recently obtained there point to $c$. 42004000/3950 BC. One should mention here the sites of Wangels, Parow, Stralsund, Baabe (Kotula et al. 2015b), Neustadt (Glykou 2016), and perhaps Lübeck-Genin (Hartz 2015), Flintbek 48 (Mischka et al. 2015) and Hamburg-Boberg 15 (Thielen, Ramminger 2015) in Germany as well as - again! Tanowo, Dabki, and Rzucewo (Galiński 2016; Kabaciński et al. 2015; Król 2018) in Poland. These sites produced remains of the early TRB, which seem to appear in the already quoted context of local hunter-gatherers that had undergone ceramisation several hundred years earlier. As mentioned above, to the east of the lower Oder River these groups, from the point of view of flint knapping, can be identified as belonging to the evolved Chojnice-Pieńki tradition, while to the west of this river they belong to the EBK tradition. Pottery revealing traits of both EBK (or rather its local derivative) and TRB, such as so-called transitional vessels from Dąki (Czekaj-Zastawny, Kabaciński 2015) and Rzucewo (Czekaj-Zastawny, Kabaciński 2018), and perhaps some forms from Tanowo (Galinski 2016), is significant in this context (Fig. 13).

However, a detailed analysis of publications presenting the above-mentioned 'Polish' sites (Kozłowski, Nowak 2018b) shows that the absolute age determinations for the earliest TRB phases are far from unambiguous, unlike quite many of the interpretations developed on their basis. This stems from the fact that all archaeological materials in these sites are vertically, and to certain degree also horizontally, mixed. Pottery fragments described as 'of the EBK type' and 'of the TRB type' (and in Dąbki also other single sherds assigned to LBK, Stroke Band Pottery culture, Brześć Kujawski culture, and Bodrogkeresztúr culture) were found virtually together. Similarly, ${ }^{14} \mathrm{C}$ dates are also mixed (e.g., the majority of ${ }^{14} \mathrm{C}$ dates in Dąbki originate from pottery), i.e. it is difficult to notice any arrangement consistent with the stratigraphy or depth (e.g., Kotula et al. 2015a.Fig. 6). As a result, as Andreas Kotula writes in another paper from the monograph on the Dabki site: "[...] in most cases the excavation 
context does not contribute to the dating, and nearly all finds could potentially be of Mesolithic or Early Neolithic age" (Kotula 2015.177). This conclusion should be extended to the sites of Tanowo and Rzucewo as well.

Thus, one can reasonably conclude that we do not have a proper insight into the chronology of the earliest TRB occupation in these sites, as smaller or greater reservations concerning the context can be expressed with respect to all the mentioned dates, not to mention the impact of the marine reservoir effect. Therefore, it comes as no surprise that the dating of the appearance of TRB pottery to $c$. 4200-4000/3950 BC (Galinski 2016. Tab. 3; Kotula et al. 2015a.122-123, 133) has been determined by the cited authors on the basis of the chronology of analogical early TRB phenomena in northern Germany, rather than on the basis of the ${ }^{14} \mathrm{C}$ dates themselves. In other words, 'Polish' dates pointing to the mentioned period have been interpreted as representing TRB rather than Late Mesolithic, because it is with this chronological horizon that the German researchers link the beginnings of TRB in northern Germany. Naturally, such a per analogiam hypothesis is fully admissible and logical. However, it needs to be emphasised that a number of other, alternative hypotheses can be formulated as well, including one positing that the dates within the 4200-4000 BC range, are actually connected still with late, ceramised Mesolithic communities, while the beginnings of TRB should be dated later, say to 4000-3800 BC or even $3800 / 3700 \mathrm{BC}$.

Whether our general approach to the chronology of the pottery from Dabki, Tanowo, and Rzucewo is correct is another issue. Is this approach not overly burdened with stereotypes and habits of culturehistorical classifications, which hamper the proper understanding of the analysed processes? In his analysis of the Mesolithic pottery from Dąbki, A. Kotula very strongly emphasizes that this pottery is technologically very similar to TRB pottery (Kotula 2015.177-178). He even concludes that "the main distinguishing criterion between the Late Mesolithic pointed bottom pots and Early Neolithic Funnel Beaker vessels is the vessel shape, but many of ki 2016).
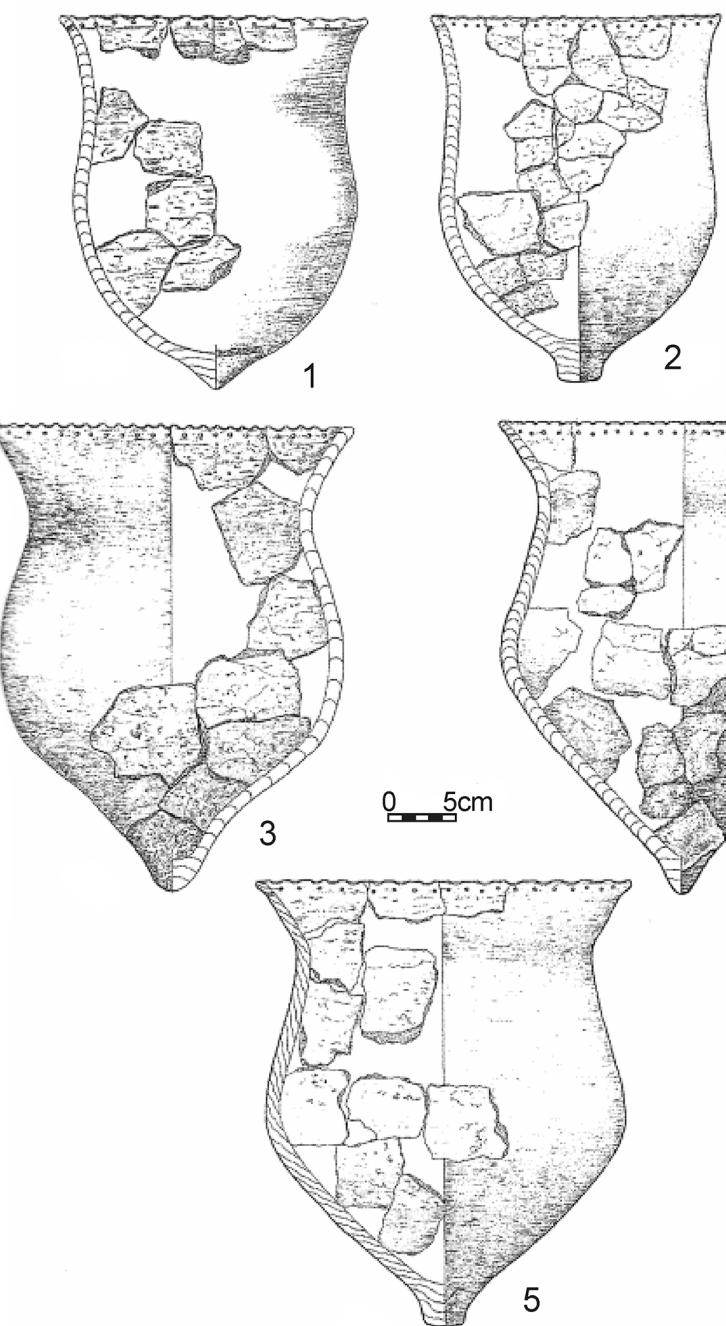

4

Fig. 10. Reconstructed pottery of the EBK from Tanowo (Galin'-

the sherds have comparable technological features. For this reason it is difficult to securely attribute pieces without specific characteristics of shape or decoration to one or the other type" (Kotula 2015. 178 ). Now, it seems clear that these sites represent some kind of an occupational, economic, social, and ideological continuum, spanning basically the $5^{\text {th }}$ and early $4^{\text {th }}$ millennia $\mathrm{BC}$, and supplemented with pottery at least from the middle of the $5^{\text {th }}$ millennium BC. The manufacture and use of this pottery is therefore also a continuum of a kind, into which we try to fit our traditional terminological bricks of EBK and TRB (to put it simply). In the case of the three sites discussed here, such 'Beaker' bricks are basically no more than certain changes in vessel shapes (but were they common?), maybe stemming from a slightly different manner of using the vessels, or some novelties in vessel decoration. The mentioned transitional pottery is particularly telling in this context (Czekaj-Zastawny, Kabacinski 2015; 2018). Yet, in this particular setting, these changes and no- 

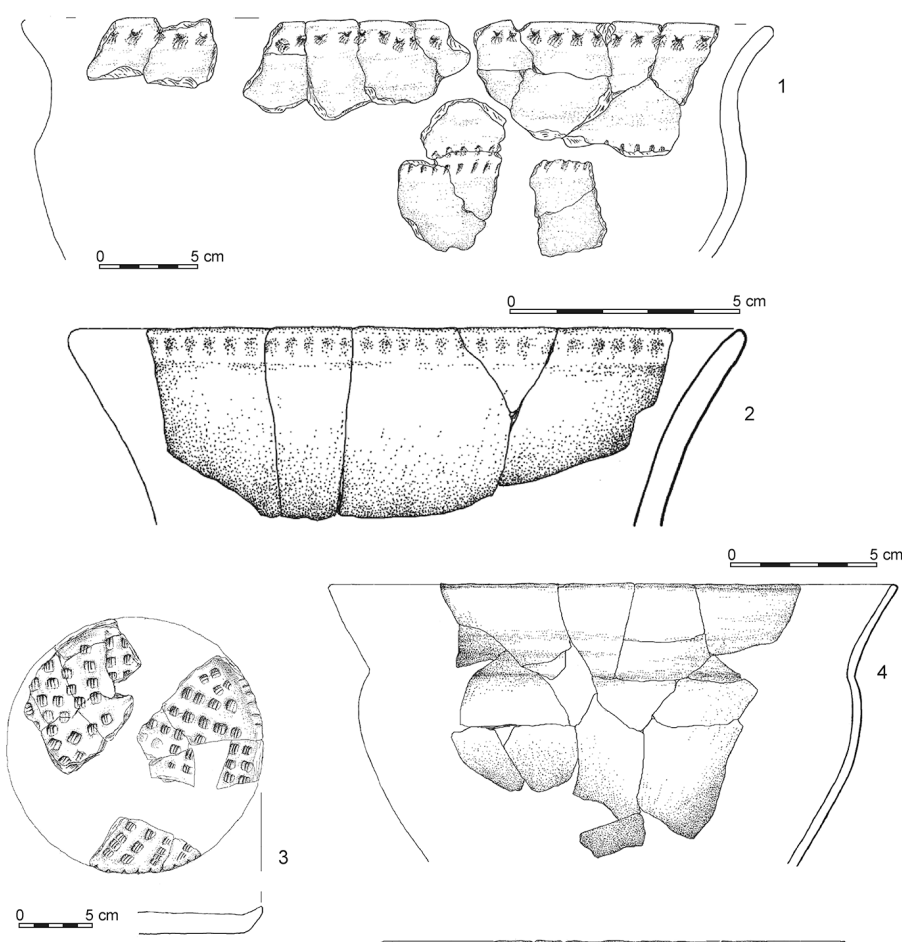

$5 \mathrm{~cm}$
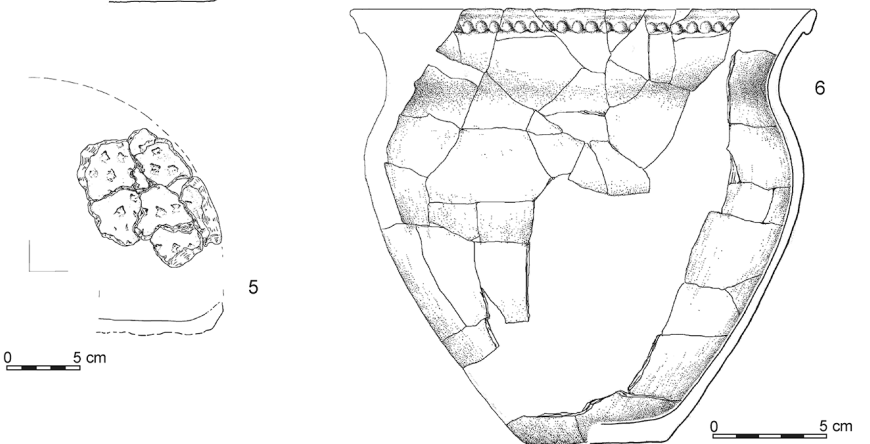

Fig. 11. Pottery of the early TRB from the site 20 in Redecz Kru kowy (Papiernik, Brzejszczak 2018).

velties, which for us formally mark TRB, did not bring about any significant change. The pottery, which can formally be labelled as EBK and TRB, can be seen as certain types, variants of the same state of pottery, produced and used by hunter-gatherer communities from the south-western coasts of the Baltic Sea throughout the $5^{\text {th }}$ and early $4^{\text {th }}$ millennia $\mathrm{BC}$. This pottery was changing gradually, with changes in manners of food preparation and consumption inspired by external influences. The changes which appear to us as 'culture-making' and therefore significant were not perceived as such by the mentioned communities.

As a result, one can express a view, which basically repeats in a more cautious manner the opinion expressed by the author in 2009 (Nowak 2009), that the south-west Baltic centre can likely be interpreted as the area where the original (first of all ceramic) version of the phenomenon known to us as the Fun- nel Beaker culture was formed, and that this took place between $c .4200$ and $4000 \mathrm{BC}$. A correction is needed to the monograph from 2009 regarding the extent of this centre - it would stretch from Holstein to eastern Pomerania. The crystallisation of the 'Beaker' patterns would be based on a strictly local, hunter-gatherer (proto-Neolithic - see further in the text) demographic and cultural substrate.

In my opinion, one cannot subscribe to the view (Czekaj-Zastawny, Kabaciński 2015; 2018; Czerniak 2018; Kotula et al. 2015a) positing that Tanowo, Dabki, or Rzucewo are connected exclusively with the northern group, and even are of 'genetic' importance for it. This can hardly be imagined in practice for reasons of geography. If the results of processes taking place there could affect territories to the north-west, why could they not affect those to the south or southeast (see, for example, Sørensen 2015. Fig. 11)?

However, from what has been written here it emerges that the south-west Baltic cradle of TRB in the last two centuries of the $5^{\text {th }}$ millennium $\mathrm{BC}$ is just one possible option. If we date the appearance of the Beaker traits in this area to a later period, e.g., around 3800/3700 $\mathrm{BC}$, it will turn out that the beginnings of TRB may have been earlier in the Polish Lowland, where they date to 3950/3900 BC at the earliest (Kukawka 2015; Nowak 2017; Papiernik, Brzejszczak 2018). In this interpretation, the TRB traits in the southwest Baltic area would originate from the south, exactly from the Polish Plain. As a reflection of the early TRB 'expansion' towards the Baltic shores one could interpret for example the site of Bielawki in eastern Pomerania (Czerniak, Rzepecki 2016). This hypothesis, however, creates a problem on a broader scale, as it implies that the earliest sites of the northern group, in northern Germany and Denmark, must be even later (c. $3700 \mathrm{BC}$ ?), which seems inconsistent with the current state of knowledge.

It also stands in opposition to those hypotheses and views which apparently extend the cradle of TRB to the west, even as far as the Netherlands. Within the core area defined in this way, covering a very large 


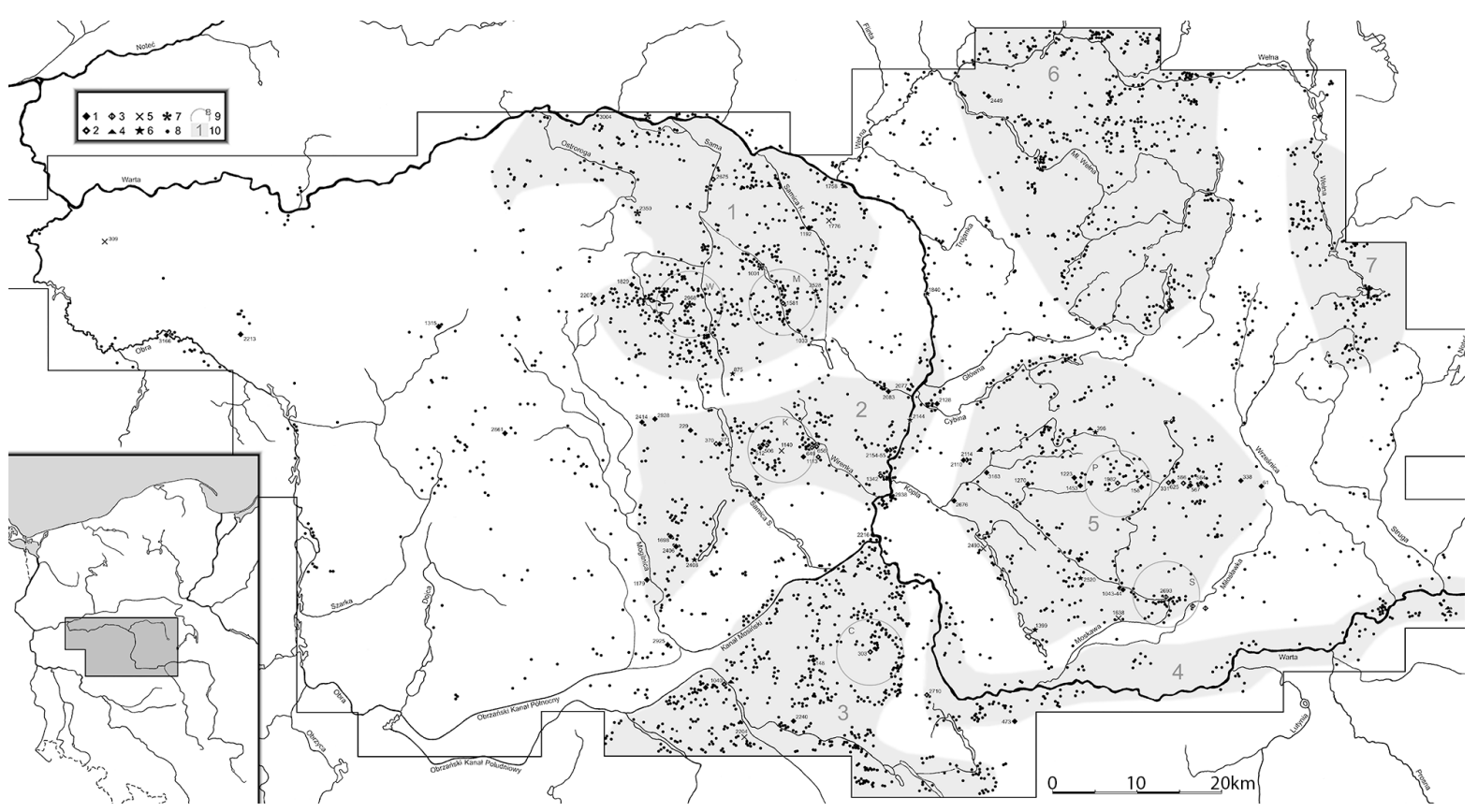

Fig. 12. The TRB sites in the middle Warta river region (Wierzbicki 2013.Fig. 4). 1-3 different categories of settlements; 4 stray finds; 5 cemeteries; 6 swamp deposits; 7 copper artefacts; 8 other sites; 9 so-called sample microregions; 10 so-called anthropomezoregions.

longitudinal span, the crystallisation of the 'Funnel Beaker' patterns is believed to have been first initiated (c. 4200-4100 BC) in the west, i.e. in the Netherlands, with ceramized Swifterbant communities as the substrate (Raemaekers 2015; Ten Anscher 2015). In this approach, in northern Germany these processes would be dated to $c .4100 \mathrm{BC}$ (Ten Anscher 2015.Fig. 15); by implication, 'Polish' sites should be given later dates, say around 4000 BC. The transformations of local hunter-gatherers into TRB is consequently seen as resulting from influences from, and contacts with, farming communities of the already formed Neolithic (the Michelsberg in particular) (Gron, Sørensen 2018; Sørensen 2015; Ten Anscher 2015), which means they are similar to 'our' Pomeranian phenomena. Views are even expressed positing the presence of 'Michelsberg' settlers, as in the case of Flintbek 15 site (Mischka et al. 2015), or more generally the agrarian (migrationrelated) and material (e.g., axes with thin butts) Michelsberg impulses (Sørensen 2015). The hypotheses promoting this area of TRB formation corroborate (but by no means prove) the idea of a south-western Baltic cradle which extended to the coastal part of Pomerania as well.

Consequently, we are of the opinion that it is still possible to assume that the zone extending along the south-western coast of the Baltic Sea was the area in which the new cultural model was formed around $4200 / 4000 \mathrm{BC}$, and from this zone this model spread to remaining parts of east-central Europe. This model was comprised of such elements as: (i) a flexible farming-herding economy, easily adaptable to different environmental conditions but at the same time showing a tendency to significant transformation of these conditions in some places (Kruk, Milisauskas 1999; Nowak 2009; Wierzbicki 2013); (ii) a relatively stable, but at the same time flexible and environmentally universal settlement pattern (Czerniak 1994; Dreczko 2019; Król 2017; Wierzbicki 2013); (iii) 'Funnel Beaker' pottery; and (iv) monumental and communal burial rites (Król 2011; Libera, Tunia 2006; Rzepecki 2011). With time and during the TRB expansion the model was surely improved and supplemented - for example, the monumental form of the burial rite appeared with some delay in relation to the beginnings of TRB.

To some extent the spread of the 'Funnel Beaker' Neolithic attributes to the remaining part of Poland took place by means of leapfrog expansion ${ }^{2}$ and ecological infiltration, advancing from the north-west starting from $c .4100 / 4000 \mathrm{BC}$. Yet, these processes were surely not the only ones responsible for the further spread of this cultural model throughout Po-

2 The terms and notions used in this and subsequent paragraphs have been developed by Zvelebil (Zvelebil 2001.2; cf. also Zvelebil, Lillie 2000.62-63). 

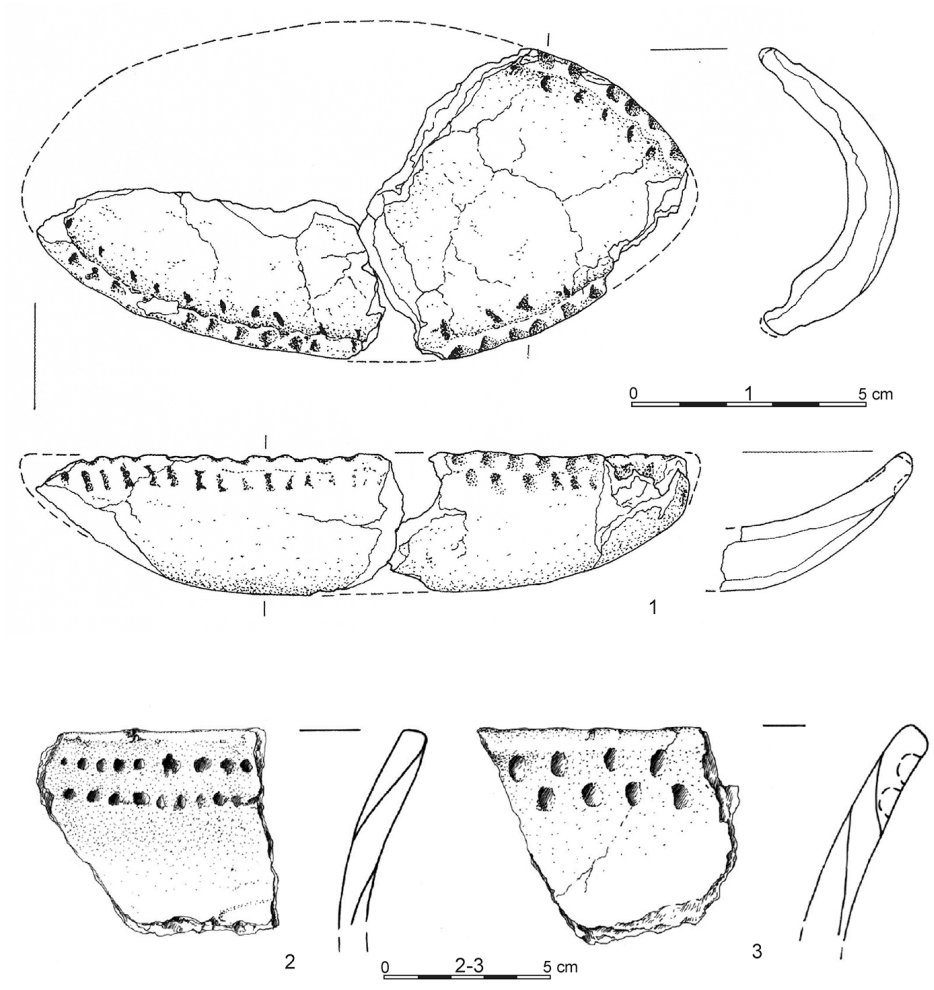

Fig. 13. Examples of so-called transitional pottery (between the EBK and TRB). 1Dabki (Czekaj-Zastawny et al. 2013); 2-3 Rzucewo (Czekaj-Zastawny, Kabaciński 2018).

land. The appeal of this model ensured its wide acceptance among populations representing various cultural milieus, both the Mesolithic and Younger Danubian groups (Fig. 14).

First of all, early TRB attributes were spread among local hunter-gatherer populations by contact and frontier mobility, and perhaps also as a result of processes resembling the domination of elites, and by c. 3650-3500 BC they had gained predominance among some of these populations. The process was facilitated by long lasting local co-existence of farming and hunting-gathering populations; after all, even limited contacts resulted in transmission of Neolithic ideas and patterns, and the practical knowledge they entailed.

Secondly, parallel with the processes described above, these attributes were also spread among Neolithic Lengyel-Polgár groups who sporadically infiltrated areas outside the 'old farming' enclaves; the mechanisms of the spread were the same.

In 'old farming' enclaves in the Polish Lowland the hitherto prevailing Neolithic culture was 'liquidated'. The processes responsible included migration, diffusion, and infiltration of the 'Meso/Neolithic' TRB population, but perhaps most importantly 'frontier' con- tacts maintained among early TRB and late Lengyel-Polgár (cf. Lorkiewicz 2012. 45-54). In turn, in Lesser Poland and Silesia the 'liquidation' of the previous Neolithic culture was the result of leapfrog colonisation, frontier mobility, and infiltration. These processes were completed around 3600-3500 BC.

To sum up, we can figuratively say that TRB (or TRB package) was a kind of a mantle which wrapped various groups and different cultural traditions ( $c f$. also Robb 2013.660).

The fact that the TRB patterns also gained general acceptance among postLinear, Neolithic groups is equally as fascinating as the TRB neolithisation of Late Mesolithic hunter-gatherers. This phenomenon is - frankly - not yet well understood and frequently neglected. This is because TRB is commonly regarded as a cultural unit par excellence of 'northern' or 'lowland' affiliation, while it actually reaches as far south as the middle Danube (near Vienna). In fact, TRB in 'southern' loess uplands reflects a blooming society or societies, as illustrated for instance by the micro region around the site of Bronocice in western Lesser Poland (Kruk et al. 1996). It is quite common for many Linear and post-Linear sites there to have been occupied by TRB people as well, as was the case with site 3 in Miechów (Fig. 15). This example demonstrates, by the way, that these TRB settlements quite often seem to be larger and much more populated.

It should be emphasised that Mesolithic and Neolithic echoes are fairly well perceived in TRB flint industries (Koztowski, Nowak 2018a), and that in fact there is no such thing as a specific TRB flint industry. Regional or even local groupings are characterized by their separate variants, which originate from earlier backgrounds, be it Late Mesolithic or Neolithic (i.e. Younger Danubian) (Fig. 16).

Unfortunately, as yet there is not much genetic data for TRB in Polish territories. In the above-quoted publication (Fernandes et al. 2018) we can read, based on only three skeletons from Kuyavia, that the TRB individuals shared a genetic composition similar to that of the Brześć-Kujawski group individuals, but with a slightly higher hunter-gatherer component. This actually corroborates quite well the 
view positing population continuity between a local branch of the Brześć Kujawski culture and TRB. To compare, in central Germany the relation between early Neolithic and Mesolithic components seems to be at a roughly similar level (Brandt et al. 2015; Haak et al. 2015); therefore a similar interpretation can be proposed. On the other hand, Scandinavian data, admittedly again very scarce, suggests the predominance of 'southern' Neolithic genetic clusters with only some admixture of local hunter-gatherers (Skoglund et al. 2012; 2014), which does not fit well with the patterns of material culture of the northern TRB.

The TRB does not make the end of the story. As we know, independent, non-Neolithic ceramic phenomena were already present in the area under consideration in the $5^{\text {th }}$ millennium BC. But in the $4^{\text {th }}$ (and actually also the $3^{\text {rd) }}$ millennium BC they significantly grew in importance. This process is not particularly well-understood, and its chronology remains far from clear as well. Perhaps this is due to its 'non-Neolithic' nature - it simply does not attract sufficient attention from specialists interested in the Neolithic. The phenomenon is represented in surprisingly vast areas (Fig. 17), throughout of almost all Poland, as some works demonstrate (Józwiak 2003; Józwiak, Domaradzka 2011; Wiślański 1979b). In archaeological terms the sites and materials linked with this phenomenon are represented mainly by the Neman culture (Fig. 18) and locally in the Mazuria by the Zedmar culture. Sometimes this phenomenon has been symbolically denoted in Polish literature as the 'Forest Neolithic', after works by Elżbieta Kempisty $(1973 ; 1983)$. It continued to flourish in the $3^{\text {rd }}$ millennium $\mathrm{BC}$ as well, as can be seen, for instance, in the recently published, very important site of Grady Woniecko (Wawrusiewicz et al. 2017).

As previously mentioned, agriculture played no role among 'Forest Neolithic' communities, with pottery still remaining the only formal reference to the Neolithic (in the classical meaning). This pottery is characterized by a certain duality. On the one hand, some of it is similar to the pottery of comparable groupings in eastern Europe, but on the other hand, another part demonstrates mixed features of the 'Forest Neolithic' and local Neolithic cultures. This branch was distinguished in the early 1970s by Kempisty (1973) as the so-called Linin type. Interestingly, four sub-types of Linin pottery were distinguished, due to the presence of Funnel Beaker, Globular Amphorae, Corded Ware, and Early Bronze elements there ( $c f$. also Józwiak 2003). This also demonstrates that hunter-gatherer groups still existed in the late $3^{\text {rd }}$ millennium BC, and that some contacts with Middle and Late Neolithic as well as Early Bronze Age communities were maintained. This is also evidenced by imports of TRB ceramic in some 


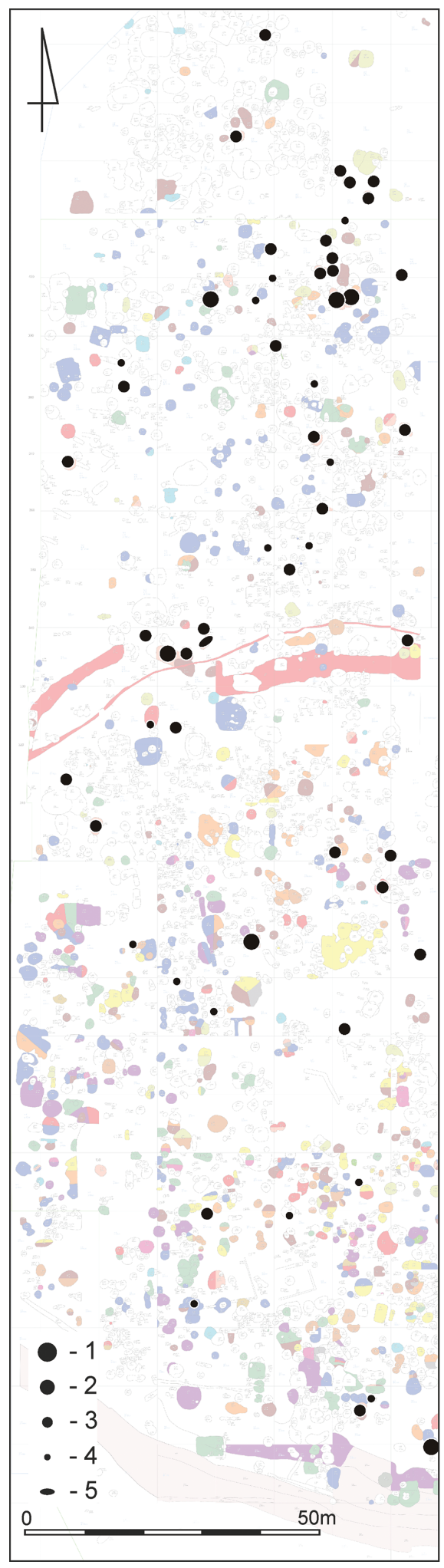

Fig. 15. The TRB settlement at the multi-period site 3 in Miechów against the blurred background of features belonging to other archaeological units; the TRB features are highlighted by graphic symbols. 1 features with longer axis over 5m; 2 features with longer axis 3-5m; 3 features with longer axis 1-3m; 4 features with longer axis less than 1m; 5 extremely elongated features (mostly burials).
'Forest Neolithic' sites (Gumiński 2011), as well as by the presence of 'Forest' ornaments and vessels in many TRB sites, particularly in Chełmno Land (Adamczak et al. 2018; Kukawka 2010).

When considering the origins of this phenomenon (the 'second', so-called southern tradition in Piezonka 2015.566, Fig. 13), the above-mentioned issue of flint inventories is of utmost importance. Specifically, 'Forest Neolithic' pottery routinely co-exists with chipped lithics of the Late Mesolithic type. In the east these lithics belong to the Janisławice tradition (e.g., Kempisty, Wieckowska 1983; Wawrusiewicz et al. 2017), and in the west to the Komornica one (e.g., Kabacinski 2016; cf. also Kozłowski, Nowak 2018a; 2018b) (Fig. 19). We can assume, by the way, that such correlations have very often passed unnoticed by modern archaeologists because in the research practice this has been considered to be a result of secondary mixing, and consequently these pottery fragments and flints were regarded as separate. Very often they landed in separate sections of different regional or even archaeological museums. It turns out that, as a result of such an approach, the materials of the Neman culture in Poland are practically devoid of flint materials. In the light of current knowledge this is not possible, so the described practice was wrong. Consequently, 'Forest Neolithic' pottery should be combined with local late-Janisławice and late-Komornica flint artefacts.

In such a situation, the strict separation between the Mesolithic and 'Forest Neolithic' loses its original sense, the two being just two branches of the same phenomenon, that is to say of the hunting-gathering populations operating in the Middle Holocene forests of the Vistula and Oder basins. The patterns of ceramic production were only transmitted from the east and south-east. These patterns were at the same time adapted and changed on the spot to some extent, among other things as an effect of contacts with the said Neolithic units. The phenomenon under discussion developed from the late $5^{\text {th }}$ millennium BC until the Early Bronze Age, simultaneously with agricultural groups.

Summing up, we should answer the question of whether two or perhaps three separate forms of neolithisation took place in Polish territories. At first glance, attempts to answer this question may seem a purely academic discussion, since the notions of the 'Neolithic' and 'neolithisation' are our creations. Were they in any way relevant for the populations of the time? We do not know, but it does not seem 
very likely. On the other hand, we know that people, even in historic times, have rarely been aware of long-lasting processes. We might ask, for example, who in the England of the late $18^{\text {th }}$ century was aware they were witnessing the beginnings of the Industrial Revolution and its early impact? Therefore, I believe we are entitled to analyse and classify various forms and variants of the neolithisation processes, irrespective of whether they were noticed by the people of that time.

Thus, it seems it is justified to speak about the differences between - so to say - LBK and TRB types of neolithisation.

The LBK neolithisation is basically a migration with a ready, complete Neolithic Package, originating entirely from the outside (people, ideas, material culture). Its inherent elements are a strict ecological selection of areas for settlement, as well as settlement and economic behaviours requiring a relatively small space.

On the other hand, neolithisation of the TRB type operated on a local hunting-gathering basis, which had already been slightly ceramicised. Although very few novelties in the history of mankind were completely independent and new, in general the TRB Neolithic model should be considered as an independent product. Among others, this model consisted of: (i) flexible settlement and economic behaviours, highly adaptable to different ecological conditions, (ii) a subsistence model usually requiring large spaces, (iii) domination of agriculture, with local deviations from this rule, and (iv) great importance of sepulchral monuments acting as visible social and ideological symbols, which were organizing the space. This TRB model turned out to be so attractive that it was also taken over by the last Younger Danubian communities.

However, only some of the Late Mesolithic huntergatherers accepted Funnel Beaker patterns. The remainder (c. 30/40\% - perhaps 'science fiction', but based on a numerical relation between 'Forest Neolithic' sites and Late Mesolithic and earlier TRB ones) successfully carried on a traditional subsistence lifestyle, gradually supplementing it with pottery. While this fact would suffice to include this phenomenon in the Neolithic from the eastern European archaeo-

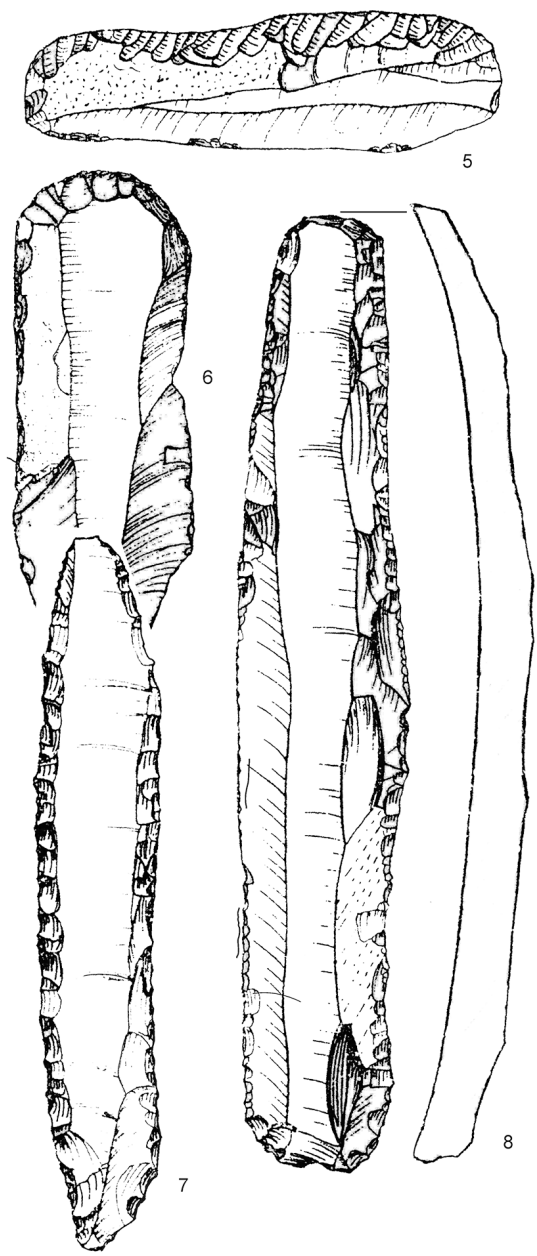

Fig. 16. Different types of chipped lithic industries of the TRB. 1-4 early, Lowland type (Redecz Krukowy 20; Papiernik, Wicha 2018); 5-8 upland, so-called Lesser Poland type (Ćmieów; Balcer 2002).

logical perspective, it is debatable whether this can be done from the perspective of more Western archaeology. Seeking an answer to this question, it should be noted that in these communities pottery was produced and used very commonly indeed. If we consider that a prerequisite for including a given unit in the Neolithic is the presence in it of only one or several elements of the Neolithic Package on a predominant level, not necessarily including food production, and if we regard the Neolithic as a new state of mind, then these conditions are fulfilled here.

What is equally important, and fascinating, is that the communities in question never adopted or imitated to any significant extent the strictly Neolithic pottery, nor the Neolithic patterns of pottery production and ornamentation. The pottery was always produced and decorated in a separate and distinct manner. It seems like the idea of pottery production itself was borrowed from the Neolithic neighbours, while the methods of implementing this idea were 


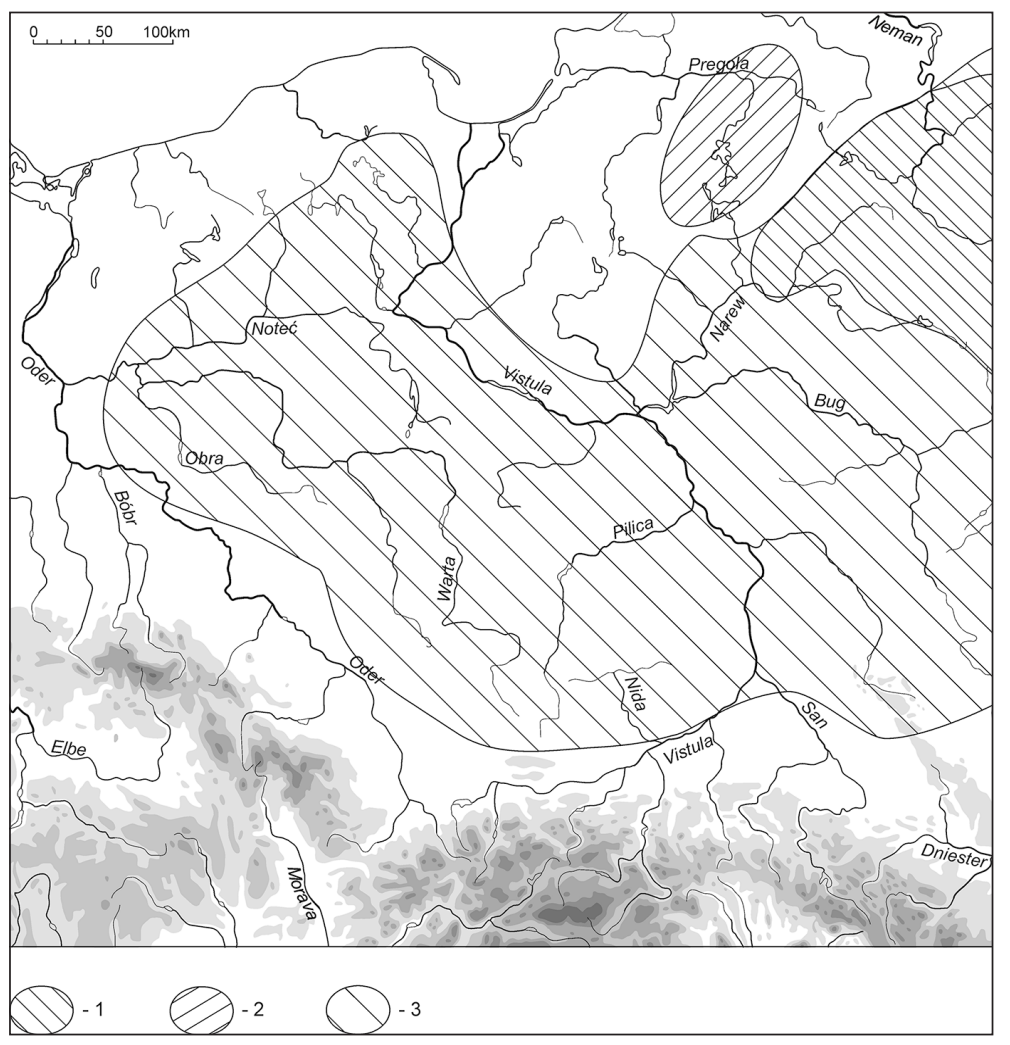

Fig. 17. The spread of the para-Neolithic in Polish territories. 1 extent of the early Neman culture in the late $5^{\text {th }}$ millennium BC; 2 extent of the Zedmar culture; 1, 3 extent of the Neman culture in the $4^{\text {th }}$ and $3^{\text {rd }}$ millennia $B C$.

not. If the details of the pottery production system were borrowed from somebody at all, it was from the neighbours/kinsmen from the east, and perhaps, in the second half of the $5^{\text {th }}$ millennium $\mathrm{BC}$, from the north-west.

Let us also add that here and there a number of other novelties appear in these communities, e.g., flint tools with surface retouching, including spear- and arrowheads, flint inserts or, in places, more frequent use of the same place for settlement. Although these are not direct determinants of the Neolithic, they demonstrate that ceramics was not the one and only thing that had changed in relation to the Mesolithic. Furthermore, as a result of more and more intensive contacts and interactions with the 'proper' Neolithic these people became wellaware that it was possible to cultivate land and raise animals, but they quite consciously did not exploit that possibility.

All these factors suggest the existence of a third, independent process, say of the eastEuropean type of Neolithisation, which in- volved certain widening of the previous spectrum of material culture and the emergence of a new (in relation to the classical Mesolithic one) state of consciousness regarding their own place in the universe. Therefore, the cultural model formed as a result of this neolithisation, in the conditions of the territory under consideration in the $5^{\text {th }}, 4^{\text {th }}$, and $3^{\text {rd }}$ millennia BC, might be included in the Neolithic.

However, if we decide that the presence, and actually predominance, of a farming-herding economy is a condition necessary for labelling a prehistoric phenomenon as Neolithic, then the 'Forest Neolithic' obviously cannot be classed as such. Similarly, the processes behind its formation cannot be called neolithisation. This does not change the fact, however, that the above-described transformations in material culture and mentality were progressing at a slower or faster pace, which means that the communities undergoing these transformations can hardly be called strictly Mesolithic. In my opinion it would be justified to use the term

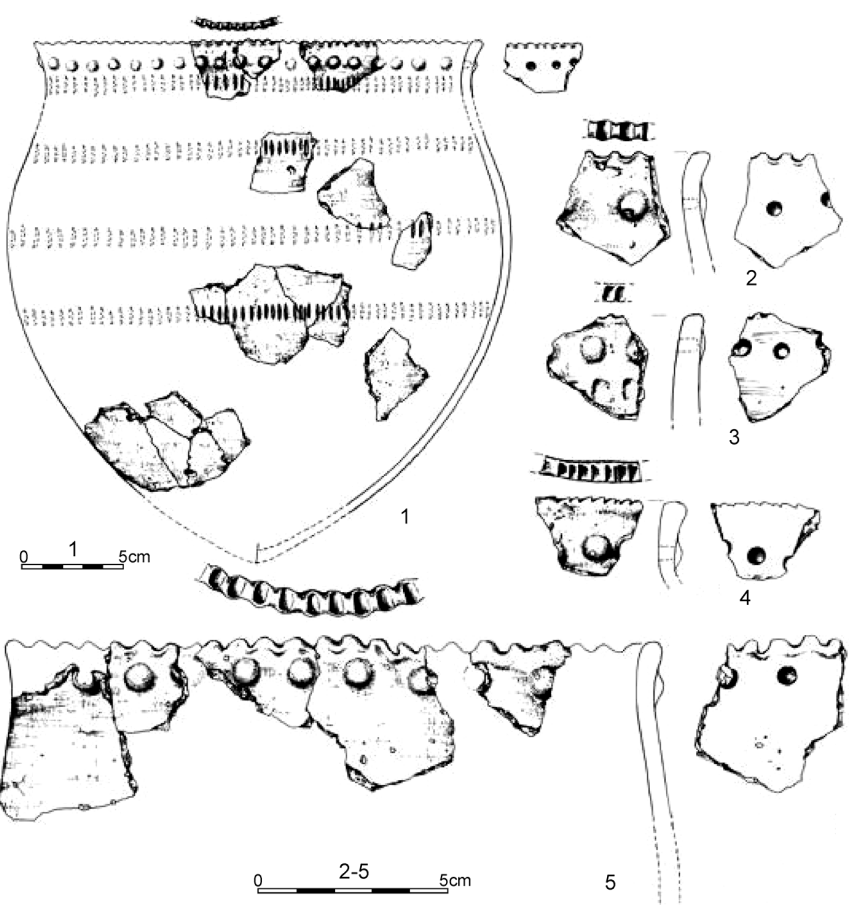

Fig. 18. Examples of the para-Neolithic pottery (Neman culture), from the site 1 in Grady Woniecko, stylistic group IIa (Wawrusiewicz et al. 2017.Fig. IV.8). 


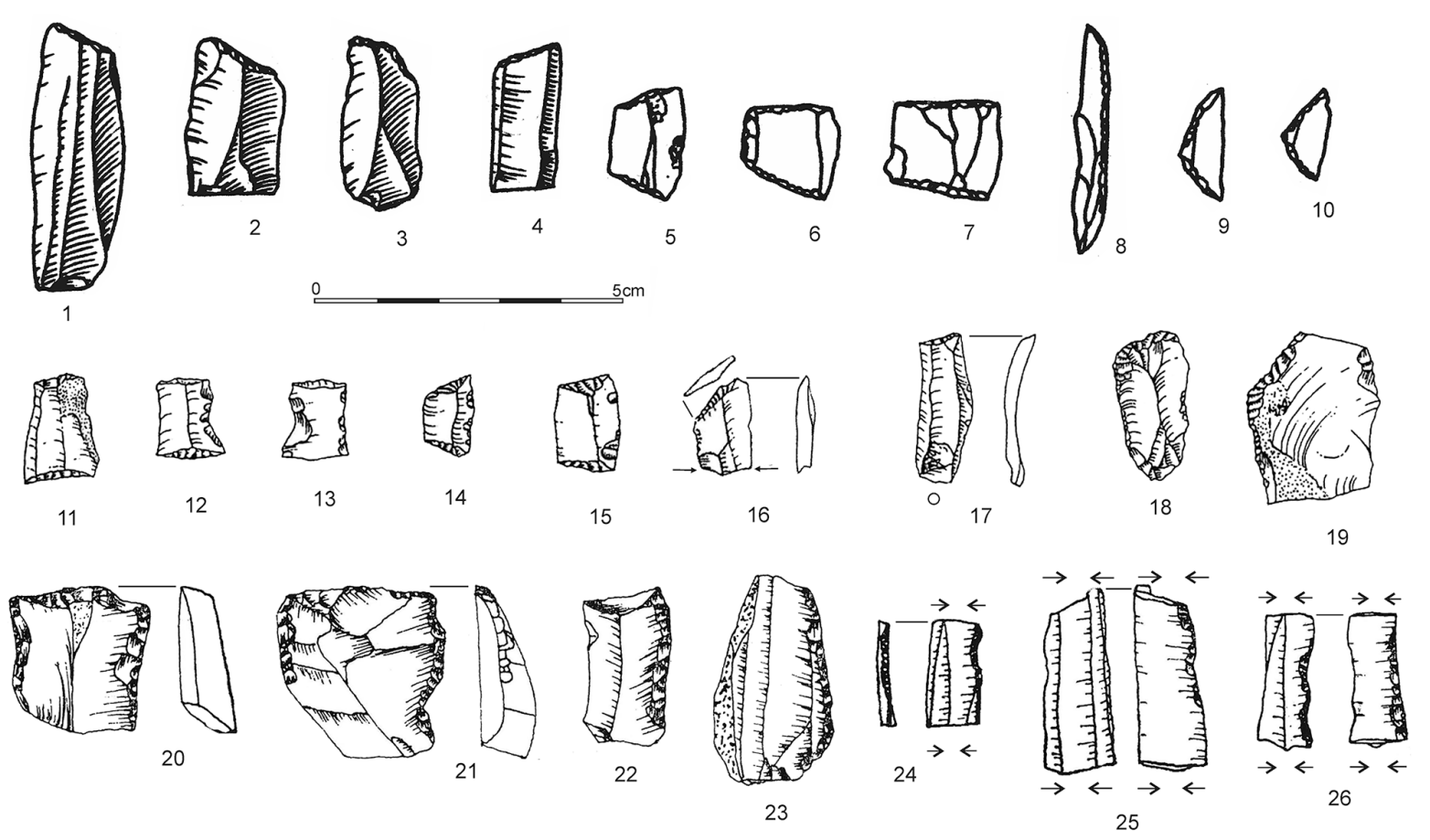

Fig. 19. Examples of chipped lithics found together with para-Neolithic pottery. 1-10 Komornica tradition (Chwalim, upper layer; Kabaciński 2016); 11-26 Janistawice tradition (11-19 tykowe; Cyrek 1990; 20-26 Wola Ranizowska; Mitura 1994).

'para- Neolithic' (quite frequently used in the literature, although in different contexts and meanings), or perhaps even 'alternative Neolithic'. They describe a formation which cannot be included either in the classic Mesolithic or the classic Neolithic, one which marks an alternative trajectory of development in the age of the Neolithic and neolithisation. One should only keep in mind that the notions of 'para-' or 'alternative-' do not have a pejorative meaning here; these were not 'defective Neolithics'. These were simply phenomena different from the Neolithic and different from the Mesolithic, distinct and specific in themselves.

The term 'proto-Neolithic', on the other hand, should in my opinion be used to describe the relatively few hunter-gatherer, 'ceramicised' groups which clearly were the demographic substrate upon which Neolithic communities developed in the late $5^{\text {th }}$ and $4^{\text {th }}$ millennia BC. In Poland, this would be the situations recorded in Dąbki, Tanowo, and Rzucewo.
Thus, to conclude, we might state that in territories of present-day Poland groups of Neolithic farmers coexisted with Late Mesolithic/proto-Neolithic/paraNeolithic hunter-gatherers throughout the whole of the Neolithic. These two worlds coexisted in close geographical proximity, although not necessarily maintaining close contacts, until the Early Bronze Age.

\section{ACKNOWLEDGEMENTS}

This work was supported by the National Science Centre of Poland (Narodowe Centrum Nauki) within the framework of the project "Cultural changes in the environment of loess uplands. Settlement, econo$m y$, and society from the Neolithic to the Middle Ages at the site no. 3 in Miechow" (no. 2016/23/B/HS3/ 00387). The author is also grateful to Piotr Godlewski for the translation of the final manuscript. 


\section{References}

Adamczak K., Kukawka S., and Małecka-Kukawka J. 2018. North-eastern periphery of the Eastern group of the Funnel Beaker culture - 80 years later. Prace i Materiały Muzeum Archeologicznego i Etnograficznego w Łodzi. Seria Archeologiczna 47(2016-2017): 69-90.

Ammerman A. J., Cavalli-Sforza L. L. 1984. The Neolithic Transition and the Genetics of Populations in Europe. Princeton University Press. Princeton.

Ammerman A., Pinhasi R., and Bánffy E. 2006. Comment on "Ancient DNA from the First European Farmers in 7500-Year-Old Neolithic Sites". Science 312: $1875 a$. https://doi.org/10.1126/science.1123936

Balcer B. 2002. Ćmielów, Krzemionki, Świeciechów. Zwiazki osady neolitycznej z kopalniami krzemienia. Instytut Archeologii i Etnologii Polskiej Akademii Nauk. Warszawa.

Bánffy E., 2004. The $6^{\text {th }}$ Millennium BC Boundary in Western Transdanubia and its Role in the Central European Neolithic Transition (the Szentgyörgyvölgy-Pityerdomb Settlement). Archaeological Institute of the Hungarian Academy of Sciences. Budapest.

2006. Eastern, Central, and Western Hungary - variations of Neolithisation models. Documenta Praehistorica 33: 125-142. https://doi.org/10.4312/dp.33.13

2019. First Farmers of the Carpathian Basin. Changing patterns in subsistence, ritual and monumental figurines. Oxford-Havertown. Oxbow.

Bánffy E., Juhász I., and Sümegi P. 2007. A prelude to the Neolithic in the Balaton region: New results to an old problem. In M. Spataro, P. Biagi (eds.), A Short Walk Through the Balkans: The First Farmers of the Carpathian Basin and Adjacent Regions. Quaderno 12. Società per la Preistoria e Protoistoria della Regione Friuli-Venezia Giulia. Trieste: 223-237.

Bentley R. A., Bickle P., Francken M., Gerling C., Hamilton J., Hedges R., Stephen E., Wahl J., and Whittle A. 2013. Baden-Würtemberg. In P. Bickle, A. Whittle (eds.), The First Farmers of Central Europe. Diversity in LBK Lifeways. Oxbow. Oxford: 251-290.

Bickle P. and 11 co-authors. 2013. Austria. In P. Bickle, A. Whittle (eds.), The First Farmers of Central Europe. Diversity in LBK Lifeways. Oxbow. Oxford-Oakville: 159-204.

Bogucki P., Grygiel R. 1993. The first farmers of Central Europe: a survey article. Journal of Field Archaeology 20: 399-426. https://doi.org/10.1179/jfa.1993.20.4.399
Bramanti B. and 15 co-authors. 2009. Genetic discontinuity between local hunter-gatherers and central Europe's first farmers. Science 326: 137-140.

https://doi.org/10.1126/science.1176869

Brandt G., Szécsényi-Nagy A., Roth Ch., Alt K. W., and Haak W. 2015. Human paleogenetics of Europe - The known knowns and the known unknowns. Journal of Human Evolution 79: 73-92.

https://doi.org/10.1016/j.jhevol.2014.06.017

Burger J., Gronenborn D., Forster P., Matsumura S., Bramanti B., and Haak W. 2006. Response to Comment on "Ancient DNA from the First European Farmers in 7500Year-Old Neolithic Sites". Science 312: $1875 b$. https://doi.org/10.1126/science.1123984

Cavalli-Sforza L. L., Menozzi P., and Piazza A. 1994. The History and Geography of Human Genes. Princeton University Press. Princeton.

Childe V. G. 1929. The Danube in Prehistory. Clarendon Press. Oxford.

1947. The Dawn of European Civilization (4th Edition). Kegan Paul, Trench, Trubner \& Co. London.

Cholewa P. 2004. Rola sudeckiego zaplecza surowcowego w kamieniarstwie neolitycznym na Ślasku. Studia Archeologiczne 34. Wydawnictwo Uniwersytetu Wrocławskiego. Wrocław.

Cyrek K. 1990. Ausgrabungen auf einer mesolitischen und neolitischen Fundstelle bei Łykowe in Mittelpolen. In P. M. Vermersch, P. Van Peer (eds.), Contributions to the Mesolithic in Europe. Papers Presented at the Fourth International Symposium "The Mesolithic in Europe", Leuven 1990. Leuven University Press. Leuven: 281-293.

Czekaj-Zastawny A. 2008. Osadnictwo społeczności kultury ceramiki wstegowej rytej $w$ dorzeczu górnej Wisty. Instytut Archeologii i Etnologii Polskiej Akademii Nauk. Kraków.

2009. The First Neolithic Sites in Central/South-East European Transect, Vol. V, Settlement of the Linear Pottery Culture in Southeastern Poland. British Archaeological Reports IS 20149. Archaeopress. Oxford.

2014. Brzezie 17. Osada kultury ceramiki wstegowej rytej. Via Archaeologica. Krakowski Zespół do Badań Autostrad. Kraków.

2015. Imported Danubian pottery in the Late Mesolithic context in Dąbki. In J. Kabaciński, S. Hartz, D. C. M. Rae- 
maekers, and T. Terberger (eds.), The Dabki Site in Pomerania and the Neolithisation of the North European Lowlands (c. 5000-3000 calBC). Archäologie und Geschichte im Ostseeraum 8. Marie Leidorf. Rahden/Westf.: 219-232.

2017. The first farmers from the south - Linear Pottery culture. In P. Włodarczak (ed.), The Past Societies. Polish Lands from the First Evidence of Human Presence to the Early Middle Ages, t. 2, 5500-2000 BC. Institute of Archaeology and Ethnology, Polish Academy of Sciences. Warszawa: 21-62.

Czekaj-Zastawny A., Kabaciński J. 2015. The early Funnel Beaker culture at Dąbki. In J. Kabaciński, S. Hartz, D. C. M. Raemaekers, T. Terberger (eds.), The Dabki Site in Pomerania and the Neolithisation of the North European Lowlands (c. 5000-3000 calBC). Archäologie und Geschichte im Ostseeraum 8. Marie Leidorf. Rahden/Westf.: 203-218.

2018. Początki osadnictwa. In D. Król (ed.), Zespót osadniczy z epoki kamienia - Rzucewo, gmina Puck, stanowisko 1. Muzeum Archeologiczne w Gdańsku. Gdańsk: 60-82.

Czekaj-Zastawny A., Kabaciński J., and Terberger T. 2011. Long distance exchange in the Central European Neolithic: Hungary to the Baltic. Antiquity 85: 43-58. https://doi.org/10.1017/S0003598X00067429

2013. Geneza kultury pucharów lejkowatych w kontekście przemian kulturowych w Europie Północnej w V tys. BC. Przegląd Archeologiczny 61: 189-214.

Czekaj-Zastawny A., Przybyła M. 2012. Modlniczka 2, powiat krakowski - cmentarzysko kultury ceramiki wstegowej rytej i osady neolityczne. Via Archaeologica. Krakowski Zespół do Badań Autostrad. Kraków.

Czekaj-Zastawny A., Zastawny A. 2006. Badania ratownicze w Brzeziu, gm. Kłaj, na stan. 17 woj. małopolskie, w latach 2003-2004. In Z. Bukowski, M. Gierlach (eds.), Raport 2003-2004, t. 2, Wstepne wyniki konserwatorskich badan archeologicznych $w$ strefie budowy autostrad $w$ Polsce za lata 2003-2004. Ośrodek Ochrony Dziedzictwa Archeologicznego. Warszawa: 509-522.

Czerniak L. 1994. Wczesny i środkowy okres neolitu na Kujawach. 5400-3650 p.n.e. Instytut Archeologii i Etnologii Polskiej Akademii Nauk. Poznań.

2018. The emergence of TRB communities in Pomerania. Prace i Materiały Muzeum Archeologicznego i Etnograficznego w Łodzi. Seria Archeologiczna 47 (20162017): 103-130.
Czerniak L., Pyzel J. 2011. Linear Pottery farmers and the introduction of pottery in the southern Baltic. Bericht der Römisch-Germanischen Kommission 89(2008): 347-360.

Czerniak L., Rzepecki S. 2016. Research on the origin of the TRB culture in east Pomerania. Pottery from Bielawki, site 5, Pelplin commune. Gdańskie Studia Archeologiczne 5: 40-58.

Davis N. 2005. God's Playground. A History of Poland. Oxford University Press. Oxford.

Dreczko E. 2018. Społeczności kultury pucharów lejkowatych na Dolnym Ślasku. Unpublished PhD thesis. Wrocław University. Wrocław.

Dumpe B., Bērziňš V., and Stilborg 0. 2011. A dialogue across the Baltic on Narva and Ertebølle pottery. Bericht der Römisch-Germanischen Kommission 89(2008): 409-442.

Fernández E., Pérez-Pérez A., Gamba C., Prats E., Cuesta P., Anfruns J., Molist M., Arroyo-Pardo E., and Turbón D. 2014. Ancient DNA analysis of 8000 B.C. Near Eastern farmers supports an early Neolithic pioneer maritime colonization of mainland Europe through Cyprus and the Aegean Islands. PLoS Genetics 10(6): e1004401. https://doi.org/10.1371/journal.pgen.1004401

Fernandes D. M. and 11 co-authors. 2018. A genomic Neolithic time transect of hunter-farmer admixture in central Poland. Scientific Reports 8: 14879.

https://doi.org/10.1038/s41598-018-33067-w

Fischer A. (ed.) 2003. The Neolithisation of Denmark: 150 Years of Debate. Continuum Group. Sheffield.

Galiński T. 2016. Protoneolit. Obozowiska towieckie ze schytku okresu atlantyckiego $w$ Tanowie na Pomorzu Zachodnim. Instytut Archeologii i Etnologii Polskiej Akademii Nauk. Warszawa.

Glykou A. 2016. Neustadt LA 156. Ein submariner Fundplatz des späten Mesolithikums and des fruehesten NeOlithikums in Schleswig-Holstein. Untersuchungen zur Subsistenzstrategie der letzten Jäger, Sammler und Fischer an der norddeutschen Ostseekueste. Wachholtz. Kiel-Hamburg.

Gron K. J., Sørensen L. 2018. Cultural and economic negotiation: a new perspective on the Neolithic Transition of Southern Scandinavia. Antiquity 92 (364): 958-974. https://doi.org/10.15184/aqy.2018.71

Gronenborn D. 2007. Beyond the models: 'Neolithisation' in Central Europe. In A. Whittle and V. Cummings (eds.), Going Over: The Mesolithic-Neolithic Transition in North- 
West Europe. Oxford University Press \& The British Academy. Oxford: 73-98.

Grygiel R. 2004. Neolit i początki epoki brązu w rejonie Brześcia Kujawskiego i Ostonek, tom I: Wczesny neolit. Kultura ceramiki wstegowej rytej. Fundacja im. K. Jażdżewskiego; Muzeum Archeologiczne i Etnograficzne w Łodzi. Łódź.

2016. Neolit i początki epoki brazu w rejonie Brześcia Kujawskiego i Osłonek, tom III: Środkowy i późny neolit. Kultura pucharów lejkowatych. Fundacja im. K. Jażdżewskiego; Muzeum Archeologiczne i Etnograficzne w Łodzi. Łódź.

Gumiński W. 2011. Importy i naśladownictwa ceramiki kultury brzesko-kujawskiej i kultury pucharów lejkowatych na paraneolitycznym stanowisku kultury Zedmar Szczepanki na Mazurach. In U. Stankiewicz and A. Wawrusiewicz (eds.), Na rubieży kultur. Badania nad okresem neolitu $i$ wczesna epoka brazu. Muzeum Podlaskie w Białymstoku. Białystok: 149-160.

Haak W. and 10 co-authors. 2005. Ancient DNA from the first European farmers in 7500-year-old Neolithic sites. Science 310(5750): 1016-1018.

https://doi.org/10.1126/science.1118725

Haak W. and 17 co-authors. 2010. Ancient DNA from European early Neolithic farmers reveals their Near Eastern affinities. PLoS Biology 8(11): e1000536.

https://doi.org/10.1371/journal.pbio.1000536.

Haak W. and 38 co-authors. 2015. Massive migration from the steppe was a source for Indo-European languages in Europe. Nature 522(7555): 207-211.

https://doi.org/10.1038/nature14317

Hamon C., Allard P., and Ilett M. (eds.). 2013. The Domestic Space in LBK Settlements. Internationale Archäologie 17. Marie Leidorf. Rahden/Westf.

Hartz S. 2015. Early Funnel Beaker pottery from LübeckGenin in northern Germany. In J. Kabaciński, S. Hartz, D. C. M. Raemaekers, and T. Terberger (eds.), The Dabki Site in Pomerania and the Neolithisation of the North European Lowlands (c. 5000-3000 calBC). Archäologie und Geschichte im Ostseeraum 8. Marie Leidorf. Rahden/Westf.: 453-464.

Hartz S., Heinrich D., and Lübke H. 2000. Frühe Bauern an der Küste. Neue ${ }^{14} \mathrm{C}$-Daten und aktuelle Aspekte zum Neolithisierungsprozeß im norddeutschen Ostseeküstengebiet. Prähistorische Zeitschrift 75: 129-229.

Hartz S., Lübke H. 2005. Zur chronostratigraphischen Gliederung der Ertebølle-Kultur und frühesten Trichterbecherkultur in der südlichen Mecklenburger Bucht. Bo- denkmalpflege in Mecklenburg-Vorpommern 52(2004): 119-144.

2006. New evidence for a chronostratigraphic division of the Ertebølle Culture and the earliest Funnel Beaker Culture on the southern Mecklenburg Bay. In C. J. Kind (ed.), After the Ice Age. Settlements, Subsistence and Social Development inthe Mesolithic of Central Europe. Konrad Theiss. Stuttgart: 59-67.

Hedges R. and 9 co-authors. 2013. The supra-regional perspective. In P. Bickle, A. Whittle (eds.), The First Farmers of Central Europe. Diversity in LBK Lifeways. Oxbow. Oxford-0akville: 343-384.

Hofmann D. 2015. What have genetics ever done for us? The implications of aDNA data for interpreting identity in Early Neolithic Central Europe. European Journal of Archaeology 18: 454-476.

https://doi.org/10.1179/1461957114Y.0000000083

Ilkiewicz J. 2005. Wczesnoneolityczne narzędzia kamienne z Pobrzeża Koszalińskiego. Folia Praehistorica Posnaniensia 13/14: 91-116.

Jakucs J. and 10 co-authors. 2016. Between the Vinča and Linearbandkeramik worlds: The diversity of practices and identities in the $54^{\text {th }}-53^{\text {rd }}$ centuries cal BC in southwest Hungary and beyond. Journal of World Prehistory 29: 267-336. https://doi.org/10.1007/s10963-016-9096-x

Jażdżewski K. 1936. Kultura puharów lejkowatych w Polsce zachodniej i środkowej. Polskie Towarzystwo Prehistoryczne. Poznań.

Józwiak B. 2003. Społeczności subneolitu wschodnioeuropejskiego na Niżu Polskim $w$ międzyrzeczu Odry $i$ Wisty. Uniwersytet im. Adama Mickiewcza w Poznaniu. Poznań.

Józwiak B., Domaradzka S. 2011. Studia nad osadnictwem społeczności subneolitycznych w Polsce północno-wschodniej. Zarys problematyki. In U. Stankiewicz, A. Wawrusiewicz (eds.), Na rubieży kultur. Badania nad okresem neolitu $i$ wczesna epoka brazu. Muzeum Podlaskie w Białymstoku. Białystok: 87-102.

Juras A. and 10 co-authors. 2017. Investigating kinship of Neolithic post-LBK human remains from Krusza Zamkowa, Poland using ancient DNA. Forensic Science International: Genetics 26: 30-39.

https://doi.org/10.1016/j.fsigen.2016.10.008

Kabaciński J. 2016. Chwalim stanowisko 1. In M. Kobusiewicz (ed.), Region Wojnowo. Arkadia łowców i zbieraczy. Ośrodek Studiów Pradziejowych i Średniowiecznych, Instytut Archeologii i Etnologii Polskiej Akademii Nauk. Poznań: 395-438. 
Kabaciński J., Hartz S., Raemaekers D. C. M., and Terberger T. (eds.) 2015. The Dabki Site in Pomerania and the Neolithisation of the North European Lowlands (c. 5000-3000 calBC). Archäologie und Geschichte im Ostseeraum 8. Marie Leidorf. Rahden/Westf.

Kabaciński J., Terberger T. 2011. Pots and pikes at Dąbki 9, Koszalin district (Poland) - the early pottery on the Pomeranian coast. Bericht der Römisch-Germanischen Kommission 89 (2008): 361-392.

Kadrow S. 2017. The Danubian world and the dawn of the metal ages. In P. Włodarczak (ed.), The Past Societies. Polish lands from the first evidence of human presence to the Early Middle Ages 2: 5500-2000 BC. Institute of Archaeology and Ethnology, Polish Academy of Sciences. Warszawa

Kempisty E. 1973. Kultura ceramiki "grzebykowo-dołkowej" na Mazowszu i Podlasiu. Wiadomości Archeologiczne 38: 3-75.

1983. Neolityczne kultury strefy leśnej w północnej Polsce. In T. Malinowski (ed.), Problemy epoki kamienia na Pomorzu. Wyższa Szkoła Pedagogiczna w Słupsku. Słupsk: 175-199.

Kempisty E., Sulgostowska Z. 1991. Osadnictwo paleolityczne, mezolityczne i paraneolityczne $w$ rejonie Woznej Wsi, woj. tomżyńskie. Instytut Historii Kultury Materialnej Polskiej Akademii Nauk. Warszawa.

Kempisty E., Więckowska H. 1983. Osadnictwo z epoki kamienia i wczesnej epoki brazu na stanowisku $1 \mathrm{w}$ Sośni, woj. łomżyńskie. Ossolineum. Wrocław-WarszawaKraków-Gdańsk-Łódź.

Kośko A. 1981. Udziat potudniowo-wschodnioeuropejskich wzorców kulturowych w rozwoju niżowych społeczeństw kultury pucharów lejkowatych. Uniwersytet im. A. Mickiewicza w Poznaniu. Poznań.

Kotula A. 2015. Contact and adaptation - the early local pottery at Dąbki and its relations to neighbouring hunter-gatherer ceramics. In J. Kabaciński, S. Hartz, D. C. M. Raemaekers and T. Terberger (eds.), The Dabki Site in Pomerania and the Neolithisation of the North European Lowlands (c. 5000-3000 calBC). Archäologie und Geschichte im Ostseeraum 8. Marie Leidorf. Rahden/Westf.: 175-202.

Kotula A., Czekaj-Zastawny A., Kabaciński J., and Terberger T. 2015a. Find distribution, taphonomy and chronology of the Dąbki site. In J. Kabaciński, S. Hartz, D. C. M. Raemaekers and T. Terberger (eds.), The Dabki Site in Pomerania and the Neolithisation of the North European Lowlands (c. 5000-3000 calBC). Archäologie und
Geschichte im Ostseeraum 8. Marie Leidorf. Rahden/Westf.: 113-136.

Kotula A., Piezhonka H., and Terberger T. 2015b. New pottery dates on the Mesolithic-Neolithic transition in the northcentral European lowlands. In J. Kabaciński, S. Hartz, D. C. M. Raemaekers and T. Terberger (eds.), The Dabki Site in Pomerania and the Neolithisation of the North European Lowlands (c. 5000-3000 calBC). Archäologie und Geschichte im Ostseeraum 8. Marie Leidorf. Rahden/Westf.: 489-509.

Kowalczyk J. 1970. The Funnel Beaker Culture. In T. Wiślański (ed.), The Neolithic in Poland. Ossolineum. Wrocław-Warszawa-Kraków: 144-177.

Kozicka M. 2017. Absolute chronology of the Zedmar culture: re-thinking radiocarbon dates. Geochronometria 44: $256-268$

Kozłowski S. K., Nowak M. 2018a. Funnel Beaker origins in Polish territories. Prace i Materiaty Muzeum Archeologicznego i Etnograficznego $w$ todzi. Seria Archeologiczna 47 (2016-2017): 289-308.

2018b. I przyszli Ludzie zza Gór Wysokich. Ziemie polskie od VI do IV tysiąclecia $B C$. in press

Król D. 2011. Chamberless Tombs in Southeastern Group of Funnel Beaker Culture. Collectio Archaeologica Ressoviensis 17. Fundacja Rzeszowskiego Ośrodka Archeologicznego; Instytut Archeologii Uniwersytetu Rzeszowskiego. Rzeszów.

2017. Społeczności kultury pucharów lejkowatych na pograniczu Podgórza Rzeszowskiego i Doliny Dolnego Sanu. Studium geograficzno-osadnicze. In M. Rybicka (ed.), Wielokulturowe cmentarzysko w Skołoszowie, stanowisko 7, pow. jarostawski, w kontekście osadnictwa z neolitu i wczesnej epoki brazu we wschodniej części Podgórza Rzeszowskiego. Uniwersytet Rzeszowski. Rzeszów: 5-24.

Król D. (ed.) 2018. Zespót osadniczy z epoki kamienia Rzucewo, gmina Puck, stanowisko 1. Muzeum Archeologiczne w Gdańsku. Gdańsk.

Kruk J., Milisauskas S. 1999. Rozkwit i upadek społeczeństw rolniczych neolitu. Instytut Archeologii i Etnologii Polskiej Akademii Nauk. Kraków.

Kruk J., Alexandrowicz S. W., Milisauskas S., and Śnieszko Z. 1996. Osadnictwo $i$ zmiany środowiska naturalnego wyżn lessowych. Studium archeologiczne i paleogeograficzne nad neolitem $w$ dorzeczu Nidzicy. Instytut Archeologii i Etnologii Polskiej Akademii Nauk. Kraków. 
Kukawka S. 2010. Subneolit pótnocno-wschodnioeuropejski na Niżu Polskim. Instytut Archeologii Uniwersytetu Mikołaja Kopernika. Toruń.

2015. Początki kultury pucharów lejkowatych na Niżu Polskim. Folia Praehistorica Posnaniensia 20: 277-300.

Kulczycka-Leciejewiczowa A. 1993. Osadnictwo neolityczne w Polsce południowo-zachodniej. Instytut Archeologii i Etnologii Polskiej Akademii Nauk. Wrocław.

2000. Early Linear Pottery communities to the north of the Sudeten and Carpathian Mountains. Recent researches. Památky archeologické. Supplementum 13: 196204.

Lazaridis I. and 119 co-authors. 2014. Ancient human genomes suggest three ancestral populations for presentday Europeans. Nature 513(7518): 409-413.

https://doi.org/10.1038/nature13673

Libera J., Tunia K. (eds.) 2006. Idea megalityczna wobrządku pogrzebowym kultury pucharów lejkowatych. Instytut Archeologii i Etnologii Polskiej Akademii Nauk, Oddział w Krakowie; Instytut Archeologii Uniwersytetu Marii Curie-Skłodowskiej. Lublin-Kraków.

Lipson M. and 56 co-authors. 2017. Parallel palaeogenomic transects reveal complex genetic history of early European farmers. Nature 551(7680): 368-372.

https://doi.org/10.1038/nature24476

Lorkiewicz W. 2012. Biologia wczesnorolniczych populacji ludzkich grupy brzesko-kujawskiej kultury lendzielskiej (4600-4000 BC). Wydawnictwo Uniwersytetu Łódzkiego. Łódź.

Lorkiewicz W., Płoszaj T., Jędrychowska-Dańska K., Ządzińska E., Strapagiel D., Haduch E., Szczepanek A, Grygiel R., and Witas H. W. 2015. Between the Baltic and Danubian worlds: The genetic affinities of a middle neolithic population from Central Poland. PLoS ONE 10(2): e0118316. https://doi.org/10.1371/journal.pone.0118316

Lüning, J. 1988a. Frühe Bauern in Mitteleuropa im 6. Und 5. Jahrtausend v. Chr. Jahrbuch des Römisch-Germanischen Zentralmuseums Mainz 35: 27-97.

Mateiciucová I. 2008. Talking Stones: The Chipped Stone Industry in Lower Austria and Moravia and the Beginnings of the Neolithic in Central Europe (LBK), 57004900 BC. Masarykova univerzita. Brno.

Mathieson I. and 116 co-authors. 2018. The genomic history of southeastern Europe. Nature 555(7695): 197-203. https://doi.org/10.1038/nature25778
Mischka D., Roth G., and Struckmeyer K. 2015. Michelsberg and Oxie in contact next to the Baltic Sea. In J. Kabaciński, S. Hartz, D. C. M. Raemaekers, and T. Terberger (eds.), The Dabki Site in Pomerania and the Neolithisation of the North European Lowlands (c. 5000-3000 calBC). Archäologie und Geschichte im Ostseeraum 8. Marie Leidorf. Rahden/Westf.: 465-478.

Mittnik A. and 21 co-authors. 2018. The genetic prehistory of the Baltic Sea region. Nature Communications 9: 442. https://doi.org/10.1038/s41467-018-02825-9

Mitura P. 1994. Obozowisko ludności subneolitycznej na stanowisku 22 w Woli Raniżowskiej - Stecach, gm. Raniżów, woj. Rzeszów. Sprawozdania Archeologiczne 46: 13-30.

Modderman P. J. R. 1988. The Linear Pottery Culture: diversity in uniformity. Berichten van de Rijksdienst voor het Oudheidkundig Bodemonderzoek 38: 63-141.

Nowak M. 2001. The second phase of Neolithization in east-central Europe. Antiquity 75(289): 582-592.

2009. Drugi etap neolityzacji ziem polskich. Instytut Archeologii Uniwersytetu Jagiellońskiego. Kraków.

2017. Geneza kultury pucharów lejkowatych: niekończąca się historia. In A. Marciniak-Kajzer, A. Andrzejewski, A. Golański, S. Rzepecki, and M. Wąs (eds.), Nie tylko krzemienie. Studia ofiarowane prof. Lucynie Domańskiej $w$ 45-lecie pracy naukowej $i 70$ rocznice urodzin. Instytut Archeologii Uniwersytetu Łódzkiego; Łódzka Fundacja Badań Naukowych, Stowarzyszenie Naukowe Archeologów Polskich, Oddział w Łodzi. Łódź: 149176.

Nowak M., Zając M., and Zakrzeńska J. in press. The Late Mesolithic in western Lesser Poland. Spectators or participants in Neolithisation? MESO 2015.

Oross K. and 10 co-authors. 2016. Longhouse times: dating the Alsónyék LBK settlement. Bericht der römischgermanischen Kommission 94 (2103): 123-150.

Papiernik P., Brzejszczak R. 2018. Osadnictwo kultury pucharów lejkowatych. In P. Papiernik, D. K. Płaza (eds.), Od epoki kamienia do wspótczesności. Badania archeologiczne w Redczu Krukowym na Kujawach, tom 1. Fundacja im. K. Jażdżewskiego. Łódź: 171-286.

Papiernik P., Wicha J. 2018. Materiały krzemienne. In P. Papiernik, D. K. Płaza (eds.), Od epoki kamienia do wspótczesności. Badania archeologiczne w Redczu Krukowym na Kujawach, tom 2. Fundacja im. K. Jażdżewskiego. Łódź: 227-344. 
Pavlů I. 2000. Life on a Neolithic Site. Bylany - Situational Analysis of Artefacts. Institute of Archaeology. Czech Academy of Sciences. Praha.

Pavlů I., Zápotocká M. 2007. Archeologie pravěkých Čech 3. Neolit. Archeologický ústav Akademie věd České republiky. Praha.

2013. The Prehistory of Bohemia 2. The Neolithic. Archeologický ústav Akademie věd České republiky. Praha.

Pazdur A., Fogtman M., Michczyński A., Pawlyta J., and Zajac M. $2004 .{ }^{14} \mathrm{C}$ chronology of Mesolithic sites from Poland and the background of environmental changes. $R a-$ diocarbon 46(2): 809-826.

https://doi.org/10.1017/s0033822200035840

Piezonka H. 2015. Jäger, Fischer, Töpfer. Wildbeutergruppen mit früher Keramik in Nordosteuropa im 6. und 5. Jahrtausend v. Chr. Archäologie in Eurasien 30. Rudolf Habelt. Bonn.

Price T. D., Bentley R. A. 2005. Human mobility in Linearbandkeramik: An archaeometric approach. In J. Lüning, C. Frirdich, and A. Zimmermann (eds.), Die Bandkeramik im 21. Jahrhundert. Symposium in der Abtei Brauweiler bei Köln vom 16.9-19.9.2002. Internationale Archäologie 7. Marie Leidorf. Rahden/Westf.: 203-215.

Prinke A., Skoczylas J. 1980. Stone raw material economy in the Neolithic of the Polish Lowland. Przeglad Archeologiczny 27: 43-85.

Prostř̌edník J., Šída P., Šrein V., Šreinová B., and Št'astný M. 2005. Neolithic quarrying in the foothills of the Jizera Mountains and the dating thereof. Archeologické rozhledy 57: 477-492.

Pyzel J. 2010. Historia osadnictwa społeczności kultury ceramiki wstegowej rytej na Kujawach. Instytut Archeologii Uniwersytetu Gdańskiego. Gdańsk.

2012. Archeologia domu na przykładzie budowli mieszkalnych kultur wstęgowych na Niżu Polskim. Perspektywy i kierunki badawcze. Gdańskie Studia Archeologiczne 2: 43-54.

Raemaekers D. C. M. 2015. Rethinking Swifterbant S3 ceramic variability. Searching for the transition to the Funnel Beaker culture before 4000 calBC. In J. Kabaciński, S. Hartz, D. C. M. Raemaekers, and T. Terberger (eds.), The Dabki Site in Pomerania and the Neolithisation of the North European Lowlands (c. 5000-3000 calBC). Archäologie und Geschichte im Ostseeraum 8. Marie Leidorf. Rahden/Westf.: 321-354.

Ramminger B. 2009. The exchange of LBK adze blades in central Europe: an example for economic investigations in archaeology. In D. Hofmann, P. Bickle (eds.), Creating Communities. New Advances in Central European Neolithic Research. Oxbow. Oxford-0akville: 80-94.

Rdzany Z. 2014. Geographical location and regional diversity of Poland. In E. Kobojek, T. Marszał (eds.), Natural Environment of Poland and Its Protection in Eódż University Geographical Research. Łódź University Press. Łódź: 9-43.

Rimantiene R. 1992. The Neolithic of the Eastern Baltic. Journal of World Prehistory 6: 97-143.

1994. Die Steinzeit in Litauen. Bericht der RömischGermanischen Kommission 75: 23-147.

Robb J. 2013. Material culture, landscapes of action, and emergent causation: A new model for the origins of the European Neolithic. Current Anthropology 54: 657-683. https://doi.org/10.1086/673859

Rück 0. 2007. Neue Aspekte und Modelle in der Siedlungsforschung zur Bandkeramik. Die Siedlung Weisweiler 111 auf der Aldenhovener Platte, Kr. Düren. Marie Leidorf. Rahden/Westf.

2012. Vom Hofplatz zur Häuserzeile. Das bandkeramische Dorf - Zeilenstrukturen und befundfreie Bereiche offenbaren eine neues Bild der Siedlungsstrukturen. In R. Smolnik (ed.), Siedlungsstruktur und Kulturwandelin der Bandkeramik. Beiträge der internationalen Tagung "Neue Fragen zur Bandkeramik oder alles beim Alten?!” Leipzig 23. bis 24. September 2010. Arbeits- und Forschungsberichte zur sächsischen Bodendenkmalpflege 25. Landesamt für Archäologie Dresden. Dresden: 20-42.

Rzepecki S. 2011. The Roots of Megalithism in the TRB Culture. Instytut Archeologii Uniwersytetu Łódzkiego; Fundacja Uniwersytetu Łódzkiego. Łódź.

Silva F., Linden M. V. 2017. Amplitude of travelling front as inferred from ${ }^{14} \mathrm{C}$ predicts levels of genetic admixture among European early farmers. Scientific Reports 7: 11985. https://doi.org/10.1038/s41598-017-12318-2

Siuchniński K. 1969. Klasyfikacja czasowo-przestrzenna kultur neolitycznych na Pomorzu Zachodnim, częśc I: Katalog źródet archeologicznych. Muzeum Pomorza Zachodniego. Szczecin.

Skoglund P. and 14 co-authors. 2014. Genomic diversity and admixture differs for Stone-Age Scandinavian foragers and farmers. Science 344: 747-750.

https://doi.org/10.1126/science.1253448

Skoglund P. and 9 co-authors. 2012. Origins and genetic legacy of Neolithic farmers and hunter-gatherers in $\mathrm{Eu}-$ 
rope. Science 336: 466-469.

https://doi.org/10.1126/science.1216304

Sørensen L. 2015. Hunters and farmers in the North - the transformation of pottery traditions and distribution patterns of key artefacts during the Mesolithic and Neolithic transition in southern Scandinavia. In J. Kabaciński, S. Hartz, D. C. M. Raemaekers and T. Terberger (eds.), The Dabki Site in Pomerania and the Neolithisation of the North European Lowlands (c. 5000-3000 calBC). Archäologie und Geschichte im Ostseeraum 8. Marie Leidorf. Rahden/Westf.: 385-432.

Stadler P., Kotova N. 2010. Early Neolithic settlement from Brunn Wolfholz in Lower Austria and the problem of the origin of (Western) LBK. In J. K. Kozłowski, P. Raczky (eds.), Neolithization of the Carpathian Basin: Northernmost distribution of the Starčevo/Körös culture. Polish Academy of Arts and Sciences \& Institute of Archaeological Sciences of the Eötvös Loránd University. Kraków-Budapest: 325-348.

Szécsényi-Nagy A. and 27 co-authors. 2015. Tracing the genetic origin of Europe's first farmers reveals insights into their social organization. Proceedings of the Royal Society B 282: 20150339.

https://doi.org/10.1098/rspb.2015.0339

Ten Anscher T. J. 2015. Under the radar: Swifterbant and the origins of the Funnel Beaker culture. In J. Kabaciński, S. Hartz, D. C. M. Raemaekers and T. Terberger (eds.), The Dabki Site in Pomerania and the Neolithisation of the North European Lowlands (c. 5000-3000 calBC). Archäologie und Geschichte im Ostseeraum 8. Marie Leidorf. Rahden/Westf.: 335-358.

Terberger T. 2006. The Mesolithic hunter-fisher-gatherers on the Northern German Plain. In K. M. Hansen, K. B. Pedersen (eds.), Across the Western Baltic. Proceedings of the archaeological conference "The Prehistory and Early Medieval Period in the Western Baltic" in Vordingborg, South Zealand, Denmark, March 27th-29th 2003. Sydsjællands Museum: 111-184.

Thielen L., Ramminger B. 2015. Mesolithic and Neolithic pottery from the inland-site Hamburg-Boberg in northern Germany. In J. Kabaciński, S. Hartz, D. C. M. Raemaekers, and T. Terberger (eds.), The Dabki Site in Pomerania and the Neolithisation of the North European Lowlands (c. 5000-3000 calBC). Archäologie und Geschichte im Ostseeraum 8. Marie Leidorf. Rahden/Westf.: 479-488.

Valde-Nowak P. 2009. Early farming adaptation in the Wiśnicz Foothills in the Carpathians. Settlements at Łoniowa and Żerków. Recherches Archéologiques NS 1: 15-36.

Wawrusiewicz A., Kalicki T., Przeździecki M., Frączek M., and Manasterski D. 2017. Grady-Woniecko. Ostatni łowcy-zbieracze znad środkowej Narwi. Muzeum Podlaskie w Białymstoku. Białystok.

Werra D. 2010. Longhouses and long-distance contacts in the Linearbandkeramik communities on the north-east border of the oecumene: "à parois doubles" in Chełmno Land (Poland). Anthropologica et Prcehistorica 121: 121-142.

2012. Długie domy społeczności kultury ceramiki wstęgowej rytej na ziemi chełmińskiej: technika podwójnych słupów. Archeologia Polski 57: 113-132.

Whittle A. 1996. Europe in the Neolithic: The Creation of the New Worlds. Cambridge University Press. Cambridge.

Whittle A. and 14 co-authors. 2013. Hungary. In P. Bickle, A. Whittle (eds.), The First Farmers of Central Europe. Diversity in LBK Lifeways. Oxbow. Oxford-0akville: 49100.

Whittle A., Bickle P. 2013. Performing LBK lifeways. In P. Bickle, A. Whittle (eds.), The First Farmers of Central Europe. Diversity in LBK Lifeways. Oxbow. Oxford-Oakville: $385-402$.

Wierzbicki J. 2013. Wielka kolonizacja. Społeczności kultury pucharów lejkowatych $w$ dorzeczu środkowej Warty. Stowarzyszenie Naukowe Archeologów Polskich, Oddział w Poznaniu. Poznań.

Wiślański T. 1979a. Kształtowanie się miejscowych kultur rolniczo-hodowlanych. Plemiona kultury pucharów lejkowatych. In W. Hensel, T. Wiślański (eds.), Prahistoria Ziem Polskich, tom II: Neolit. Ossolineum. WrocławWarszawa-Kraków-Gdańsk: 165-260.

1979b. Krąg ludów subneolitycznych w Polsce. In W. Hensel, T. Wiślański (eds.), Prahistoria Ziem Polskich, tom II: Neolit. Ossolineum. Wrocław-Warszawa-Kraków-Gdańsk: 319-336.

Zvelebil M. 1998. Agricultural frontiers, Neolithic origins, and the transition to farming in the Baltic Basin. In M. Zvelebil, L. Domańska, and R. Dennell (eds.), Harvesting the Sea, Framing the Forest: The Emergence of Neolithic Societies in the Baltic Region. Sheffield Academic Press. Sheffield: 9-28.

2001. The agricultural transition and the origins of Neolithic society in Europe. Documenta Praehistorica 28: 1-27. https://doi.org/10.4312/dp.28.1

Zvelebil M., Lillie M. 2000. Transition to agriculture in Eastern Europe. In T. D. Price (ed.), Europe's First Farmers. Cambridge University Press. Cambridge: 57-93. 